\title{
HEINONLINE
}

Citation: 52 Vand. L. Rev. 11671999

Content downloaded/printed from

HeinOnline (http://heinonline.org)

Wed Nov 6 13:55:54 2013

-- Your use of this HeinOnline PDF indicates your acceptance of HeinOnline's Terms and Conditions of the license agreement available at http://heinonline.org/HOL/License

-- The search text of this PDF is generated from uncorrected OCR text.

-- To obtain permission to use this article beyond the scope of your HeinOnline license, please use:

https://www.copyright.com/ccc/basicSearch.do?

\&operation $=$ go\&search Type $=0$

\&lastSearch $=$ simple \&all $=0$ on \& titleOrStdNo $=0042-2533$

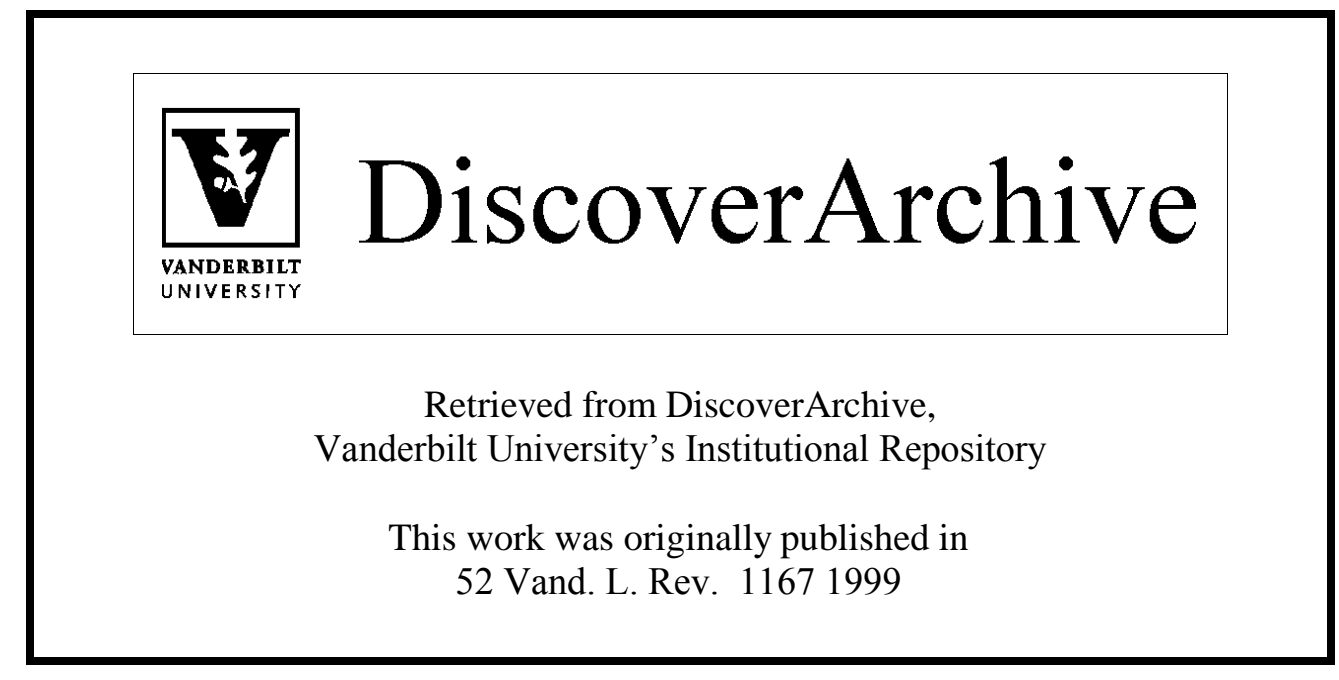




\section{Institutional Design and the Lingering Legacy of Antifederalist Separation of Powers Ideals in the States}

52 Vand. L. Rev. 1167 (1999)

This Article applies comparative institutional analysis to separation of powers under state constitutions, with a particular focus on the nondelegation doctrine and states' acceptance of Chadha-like restrictions on legislative oversight. The Article begins by contrasting state and federal doctrine and enforcement levels in each of these separation of powers contexts. Most state courts, unlike their federal counterparts, adhere to a strong nondelegation doctrine. In addition, many states accept (de facto if not de jure) even more explicit and sweeping legislative vetoes than the federal system. The Article highlights the contrast of federal and state approaches by identifying their similarity with Federalist and Antifederalist separation of powers principles, respectively.

Once the contrast is drawn, the Article develops a descriptive explanation for this divergence in jurisprudential approach. After discussing the pitfalls of common American heritage, textual, and culture-based approaches to interpreting separation of powers in state constitutionalism, the Article presents institutional analysis as a better explanation for divergences in interpretive approach. Specifically, the Article discusses institutional design in the legislative and executive branches of states, and its interrelationship with faction and capture of the agency decisionmaking process. Attention to institutional design can explain adherence to the nondelegation doctrine in many states, and can also explain the explicit and sweeping presence of legislative vetoes in some states. In addition, attention to institutional design features and their interrelationship with faction in the decisionmaking process can help to shed light on doctrinal nuances of state court approaches to upholding and striking certain delegations, such as delegations to private boards and to federal agencies. Thus, an appreciation of the role of institutional design is a necessary predicate to the development of an independent state theory of separation of powers. 


\section{Institutional Design and the Lingering Legacy of Antifederalist Separation of Powers Ideals in the States}

Jim Rossi

I. INTRODUCTION.

II. SEPARATION OF POWERS AS A CONSTRAINT ON AGENCY

RULEMAKING IN THE FEDERAL SYSTEM ............................

A. The Nondelegation Doctrine

B. INS v. Chadha: Judicial Invalidation of the

Legislative Veto

C. Connecting the Two Strands: The Convergence of

Rationales for Separation of Powers

III. SEPARATION OF POWERS AS A CONSTRAINT ON

STATE AGENCY RULEMAKING

A. Separation of Powers Provisions in State

Constitutions

B. $\quad$ State Approaches to Nondelegation ..................... 1191

1. "Weak" Nondelegation States ................... 1191

2. "Strong" Nondelegation States .................. 1193

* Patricia A. Dore Associate Professor of State Administrative Law, Florida State University College of Law. Thanks to members of the National Association of Administrative Rules Review, for giving me the opportunity to explore this topic in a presentation at the Council of State Governments 1997 Annual Meeting in Honolulu, Hawaii. Since then, the Article has benefited from comments by Matthew Adler, Scott Boyd, James Gardner, John Gedid, Steven Gey, Jessica Korn, Harold Krent, Jerry Mashaw, Robert Pushaw, John Rohr, Joshua Sarnoff, Mark Seidenfeld, Peter Strauss, Alan Tarr, and Robert Williams. I am grateful to them for their encouragement and (more important) criticism and te Mary McCormick for her assistance with research. All errors and misinterpretations are my own, not theirs. 
3. "Moderate" Nondelegation Doctrine

1198

C. Rules Review and Separation of Powers in the

States.

1201

IV. STATE CONSTITUTIONAL INTERPRETATION AND

INSTITUTIONAL DESIGN.

1216

A. The Limits of Common American Heritage,

Textual, and Character Interpretivism.

1217

1. The "Common American Heritage"

Approach ............................................ 1218

2. The Textual Approach........................... 1220

3. The "Political Culture" Approach ............. 1221

B. Institutional Design, the Legacy of Antifederalist

Separation of Powers Ideals, and State

Constitutional Interpretation.

1. Institutional Design and Nondelegation

Doctrine

2. Institutional Design and the Need for

More Continuing Legislative Control,

Not Just Oversight...

1229

3. Constitutional Interpretation and

Institutional Design

1232

V. CONCLUSION

1238

\section{INTRODUCTION}

In confronting important constitutional issues, state courts face a range of interpretive questions, many unanswered by the texts of state constitutions. Where a constitutional text fails to answer the question posed, a state court, much like its federal counterparts, ${ }^{1}$ must look to extra-textual interpretive tools to aid in its decisionmaking task. The literature on state constitutional law provides important insights into how interpretation operates within a single state's. system of governance. ${ }^{2}$ But rarely does it attempt to under-

1. See generally PHILIP BOBbitT, CONSTItutional INTERPRETATION (1991); RONALD DWORKIN, LAW's EMPIRE (1986).

2. Often this occurs in centennial symposia celebrating state constitutions. See generally' Gordon B. Baldwin, Celebrating Wisconsin's Constitution 150 Years Later, 1998 WIS. L. REV. 661 (introducing symposium issue). 
stand and appreciate how or why the interpretive practices of state and federal constitutional systems differ.

This is unfortunate. Understood through the lens of a comparative method, state constitutional law takes on a new level of richness. Of course, many have argued that state constitutions are unique and that state constitutional interpretation ought to adjust to the "character" of the people of a state or region, suggesting a variety of distinct interpretive approaches between the states. ${ }^{3}$ Apart from this argument, suggested by many advocates of the new judicial federalism, ${ }^{4}$ there is hittle discussion of state courts' divergence in result from federal courts in deciding similar constitutional issues.

In fact, in contrast-and perhaps in reaction-to characterbased interpretive arguments, some have suggested that state courts seek out common American values, disregarding or discounting peculiar features of their own systems of governance. ${ }^{5}$ According to Paul $\mathrm{Kahn}$, efforts of state courts to ground constitutional interpretation in "unique state sources," whether textual or attitudinal, is anachronistic, because Americans identify with a national community and share fundamental values. ${ }^{6}$ James Gardner, a consistent critic of the new judicial federalism, also endorses a notion of national unity in state constitutional interpretation. Gardner argues that a state court should "part company with the United States Supreme Court for no

3. For example, Robert Post writes that "[c]onstitutional law is fundamental because it reflects and embodies the essential political ethos that makes governance possible within a particular culture." Robert C. Post, The Challenge of State Constitutions, in ConstituTional REFORM In CALIFORNIA: MAKING STATE GOVERNMENT MORE EFFECTIVE AND RESPONSIVE 45, 45 (Bruce E. Cain \& Roger G. Noll eds., 1995). See also A.E. Dick Howard, State Courts and Constitutional Rights in the Day of the Burger Court, 62 VA. L. REV. 873, 938-39 (1976) (noting state constitution is a "mirror of fundamental values"). The judges and justices sitting on their state's highest courts frequently claim that their constitutions reflect unique values. See, e.g., Shirley S. Abrahamson, Reincarnation of State Courts, 36 Sw. L.J. 951, 965 (1982) (Wisconsin Supreme Court Justice, lecturing that a state constitution should be interpreted in light of its "peculiarities," including "its land, its industry, its people, [and] its history"); Judith S. Kaye, Dual Constitutionalism in Practice and Principle, 61 ST. JoHN's L. REv. 399, 423 (1987) (Associate Judge of the New York Court of Appeals, observing that "[m]any states today espouse cultural values distinctively their own"); Robert F. Utter, Freedom and Diversity in a Federal System: Perspectives on State Constitutions and the Washington Declaration of Rights, in DeVElopments IN STATE ConstituTional LAW 239, 244 (Bradley D. McGraw ed., 1985) (Associate Justice of the Washington Supreme Court, arguing that his state's constitution should be interpreted in light of "the vast differences in culture, pohtics, experience, education and economic status" between the state and national founding periods).

4. For discussion and criticism, see James A. Gardner, Southern Character, Confederate Nationalism, and the Interpretation of State Constitutions: A Case Study in Constitutional Argument, 76 TEX. L. REV. 1219, 1227 (1998) (concluding that "the character differentiation hypothesis does not hold up').

5. See id.; infra note 6.

6. Paul W. Kahn, Interpretation and Authority in State Constitutionalism, 106 HARV. L. REV. 1147, 1159-60 (1993). 
other reason than, in the state court's view, the Supreme Court has gotten it wrong."7

Yet, it should come as no surprise that, in practice, a lockstep approach is rarely followed. State courts sometimes reach different results than their federal counterparts in deciding issues of constitutional law because states are distinct institutions of governance, in terms of their sizes, decisionmaking structures, populations, and histories. In recent years, institutional features of governance have received much attention in a growing literature known as "comparative institutional analysis." Unlike character-based approaches to comparative state constitutionalism, which view constitutional interpretation as each state's attempt to identify the ethos of its pohty, an institutional approach attempts to develop general observations about how governmental structures influence or demand distinct approaches to constitutional interpretation. A comparative institutional explanation of constitutional difference begins from the assumption that structural differences affecting constitutional interpretation outweigh structural similarities, and that these institutional differences provide a better explanation for diverging interpretive approaches than differences in culture or region. ${ }^{9}$

In this Article I set out to explore how, if at all, institutional analysis can shed hight on state constitutional interpretive practice and the understanding of state constitutional law. I focus my inquiry on one particular jurisprudential aspect of state constitutions-separation of powers-but the analysis has imphications for other constitutional issues. Separation of powers is a broad set of democratic principles. These principles find expression in a variety of jurisprudential doctrines, ${ }^{10}$ but two particular doctrines have greatly influenced the

7. Gardner, supra note 4, at 1289.

8. See generally NEIL K. KOMESAR, IMPERFECT ALTERNATIVES: CHOOSING INSTITUTIONS IN LAW, ECONOMICS, AND PUBLIC POLICY (1994) (advocating increased role for comparative institutional analysis in law); see also Neil K. Komesar, Exploring the Darkness: Law, Economics, and Institutional Choice, 1997 WIS. L. REV. 465. In legal analysis, comparative institutional analysis has perhaps been most fully explored in the context of international law. See generally William J. Aceves, Institutionalist Theory and International Legal Scholarship, 12 AM. U. J. INT'L L. \& POL'Y 227 (1997); Joel P. Trachtman, The Theory of the Firm and the Theory of the International Economic Organization: Toward Comparative Institutional Analysis, 17 NW. J. INT'L L. \& BUS. 470 (1996-97).

9. The approach is similar to Dan Rodriguez's recent call for a "trans-state" constitutionalism, in which constitutional issues are not jurisdiction-specific but "raise similar stakes and have more or less similar shapes." Daniel B. Rodriguez, State Constitutional Theory and its Prospects, 28 N.M. L. REv. 271, 301 (1998).

10. Some of these doctrines inform the power and limits of the judiciary. See, e.g., Lea Brilmayer, The Jurisprudence of Article III: Perspectives on the "Case or Controversy" Require- 
power of agencies to promulgate rules and to take other regulatory action: (1) the nondelegation doctrine, which places limits on the ability of a legislative body to delegate decisionmaking authority to an agency; and (2) limitations on legislative oversight by the exercise of unilateral actions that trump agency decisions absent some executive acquiescence.

Part II of this Article introduces the approach of federal courts in deciding separation of powers matters. In the federal system, postNew Deal separation of powers jurisprudence lias recognized the relevance of these doctrines but supports different enforcement levels for each. Federal courts have weakly enforced the nondelegation doctrine by applying something similar to the test endorsed in the 1960s by Kenneth Culp Davis. Davis urged courts to accept a delegation of power made with a vague "intelligible principle" so long as adequate "procedural safeguards" are in place." At the same time, at least since the U.S. Supreme Court's decision in INS v. Chadha, ${ }^{12}$ limits on unilateral legislative trumps on executive exercises of delegated power, such as the legislative veto, have been strongly enforced by federal courts. When these two aspects of separation of powers are considered together, our federal system might be said to endorse a strong prodelegation separation of powers jurisprudence- one that generally favors delegation to administrative agencies, while precluding congressional delegation with strings attached.

The founders of our Constitution could not possibly have envisioned the scope and size of the modern administrative state. Yet, I shall argue, the prodelegation position shares some intellectual principles with the Federalist political science of the founding era, which recognized separation of powers but favored a blended or mixed conception of separation of powers over a more rigid interpretation that was popular in state constitutions at the time.

Some states decide these issues in a manner almost identical to federal courts, but many state courts approach separation of pow-

ment, 93 Harv. L. Rev. 297, 302-06 (1979); Henry M. Hart, Jr., The Power of Congress to Limit the Jurisdiction of Federal Courts: An Exercise in Dialectic, 66 HARv. L. REV. 1362, 1365 (1953); Robert J. Pushaw, Jr., Justiciability and Separation of Powers: A Neo-Federalist Approach, 81 CORNELL L. REV. 393, $413-15$ (1996); Lawrence Gene Sager, Constitutional Limitations on Congress' Authority to Regulate the Jurisdiction of the Federal Courts, 95 HARV. L. REV. 17, 37. 42 (1981); Herbert Weschler, The Courts and the Constitution, 65 COLUM. L. REV. 1001 (1965). Separation of powers with respect to the judiciary is beyond the scope of my inquiry.

11. See Kenneth Culp Davis, A New Approach to Delegation, 36 U. CHI. L. REv. 713, 725 (1969) (suggesting that "the exclusive focus on standards should be shifted to an emphasis more on safeguards than on standards").

12. INS v. Chadha, 462 U.S. 919 (1983). 
ers jurisprudence differently. In Part III, I argue that the approaches of many states have origins in Antifederalist political thought and the early constitutions of the colonies. ${ }^{13}$ Modern state courts take a variety of approaches, but most state courts reject Davis' view of separation of powers. In many states, courts impose substantive limits on delegation. Legislatures are not allowed to delegate to agencies unless they have articulated reviewable standards to guide agency discretion, even where procedural safeguards are in place. At the same time, many states accept a legislative oversiglit role for agency rulemaking not allowed Congress. In some states, legislative veto or oversight committee suspension of rules is constitutionally authorized; in others, the state legislature or legislative committees are given far broader oversight roles-eitler de jure or de facto-with respect to agency rulemaking than the U.S. Congress. This contrasts with the federal approach to the extent it disfavors agency exercise of discretion absent some explicit acquiescence by the legislature, either in more specific acts of delegation or in legislative approval of administrative rules. ${ }^{14}$ Like Antifederahst political science, many states, more than federal courts, view separation of powers as requiring complete separation of functions and most states see the legislature as the supreme lawmaker. The prodelegation approach and Chadha's prohibition on the legislative veto, endorsed by federal courts, is inconsistent witl some Antifederahist separation of powers principles.

In Part IV of the Article, I apply theories of state constitutional interpretation to the separation of powers issue with the intention of identifying an independent state theory of separation of powers; one that might explain why Antifederalist separation of powers ideals linger in the states. While my analysis provides some explanation for

13. In contrasting Federalist and Antifederahist political thought, I am focusing on their understandings of separation of powers and its applications to the relationslip between legislatures and executives, not on their differing views of the powers of a central government vis-à-vis the states. Although the powers of a central government and its impacts on individual rights were clearly a concern to the Antifederalists, see generally JACKSON TURNER MAIN, THE ANTIFEDERALISTS: CRITICS OF THE CONSTITUTION 1781-1788 (1961), separation of powers was also an important concern in their political philosophy. Gordon Wood observes that, because many had come to view separation of powers "as an essential precaution in favor of liberty ... it was perhaps inevitable that the Antifederalists would invoke the notion of separation of powers in opposition to the Constitution." GORDON S. WOOD, THE CREATION OF THE AMERICAN REPUBLIC 1776-1787, at 549 (1969).

14. By developing an anti-delegation separation of powers paradigm, 1 do not intend to suggest that this idea is in fashion among all or even most of the states. Rather, by highlighting the extreme position, endorsed in a few states, I only intend to illustrate the contrast between the federal and many states' approaches for purposes of developing an explanation for state approaches. 
the approach of many state courts, I do not intend to defend or justify Antifederalist separation of powers ideals. Instead, my observations are directed to the reasoning-not the result-of state court opinions. Regardless of result, state courts rarely make explicit the Antifederalist principles behind their decisions, nor do they point to the institutional features that might explain their decisions. Instead, they attempt to ground their interpretive decisions in common American heritage or textual arguments. In doing so, state courts ignore or bury in doctrinal subterfuge the micropolitical factors that influence their doctrinal approaches.

An appreciation of the institutional design of state systems of administrative governance provides insight as to how state courts should seek out certain values-particularly values associated witl sound institutional governance-in performing their interpretive task. Specifically, as I suggest, key institutional differences between state legislatures and the United States Congress, as well as some differences between the structure of executive governance between the states and the President of the United States, may have worked to perpetuate Antifederalist principles in state separation of powers jurisprudence. ${ }^{15}$ The role of institutional design factors should not be exaggerated, but some attention to institutional design helps to shed hght on state courts' interpretive approacl in adhering to Antifederalist separation of powers ideals. ${ }^{16}$ While there are normative grounds for critiquing the interpretive approacls of state courts in addressing separation of powers issues, especially wlien compared to

15. I am not making a causal historical claim. The institutional design features I discuss do not have Antifederalist origins. Rather, I intend to argue that contemporary institutional design, whatever its historical origins, seems to perpetuate Antifederalist ideals. State constitution institutional design typically has more recent origins.

16. The contribution of institutional factors to separation of powers jurisprudence has been discussed in more particularized separation of powers contexts. See HaroId H. Bruff, Separation of Powers Under the Texas Constitution, 68 TEx. L. REV. 1337, 1346 (1990) (arguing that "the strength and nature of the relationships between agencies and the constitutional branches" are important to understanding Texas' separation of powers jurisprudence, and that "the differences between federal and state governments may prove important to the analysis"); John Devhn, Toward a State Constitutional Analysis of Allocation of Powers: Legislators and Legislative Appointees Performing Administrative Functions, 66 TEMP. L. REv. 1205, 1211 (1993) (observing "there are systematic differences between the federal government and the states with respect to their constitutions and their place in the American scheme of government, and that these differences make the development of an independent theory of state constitutional allocation of governmental powers both possible and desirable"). This Article generalizes and develops further some of Bruff and Devlin's insights, utilizing the more comprehensive method of comparative institutional analysis. For a recent discussion of how comparative institutional competence affects the application of rationahty review in state courts, see Helen Hershkoff, Positive Rights and State Constitutions: The Limits of Federal Rationality Review, 112 HARV. L. REV. 1131 (1999). 
the approach of federal courts, a careful analysis of institutional difference is necessary to understand why Antifederalist ideals continue to surface in many states. In addition, institutional design factors help us understand why state courts strike or uphold various delegations, and why states accept more formalized oversight roles for legislatures than their federal counterparts. In deciding separation of powers issues, state courts seeking an independent justification for their decisions should make explicit Antifederalist separation of powers principles and discuss the institutional features in their own systems of governance that affect the division of powers. Such an approach would aid state courts in borrowing decisions and rationales from other jurisdictions. Also, I conclude, to the extent the Antifederalist legacy is misguided in the state separation of powers context, institutional reform of state legislatures and executive offices may make its abandonment more plausible.

\section{SEPARATION OF POWERS AS A CONSTRAINT ON AGENCY RULEMAKING IN THE FEDERAL SYSTEM}

[P]erhaps there was no argument urged with more success, or more plausibly grounded against the Constitution ... than that founded on the mingling of the Executive and Legislative branches of Government in one body. ${ }^{17}$

James Madison's comment during the First Congress evidences the importance of competing visions of separation of powers during the founding era. The notion of separation of powers, rooted in the philosophies of Locke ${ }^{18}$ and Montesquieu, ${ }^{19}$ has foundations that have been traced to the ancient Greek and Roman theories of mixed

17. I ANNALS OF CONGRESS 374.

18. Although Locke regarded the legislative power as supreme, he did not believe it should be arbitrary. See JOHN LOCKE, SECOND TREATISE OF GOVERNMENT \$§ 135-37, (C.B. Macpherson ed., 1980) (1690). In Locke's view, expressed in the opening sentence of the Declaration of Independence, the legislative power was subject to dissolution by the people. See id. $\$ \$ 220-22$. It was also subject to the prerogative of the executive. See id. at cl. XIV; see also Suri Ratnapla, John Locke's Doctrine of Separation of the Powers: A Re-Evaluation, 38 AM. J. JURIS. 189, 196-220 (1993).

19. Montesquieu justified separation of powers on the grounds that it protected against the encroachment of liberty by government. He wrote that "[w] hen legislative power is united witl executive power in a single person or in a single body of the magistracy, there is no liberty, because one can fear that the same monarch or senate that makes tyrannical laws will execute them tyrannically." MONTESQUIEU, THE SPIRIT OF THE LAWS 157 (Anne M. Cohler et al. eds. \& trans., 1989). 
government. ${ }^{20}$ Prior to adoption of the Constitution, the American colonies and Articles of Confederation endorsed notions of separation of powers but in ways designed to protect and expand legislature power. The Articles define the legislature as the primary lawmaking body that actively participates in every aspect of governance. ${ }^{21}$ Similarly, in the colonies at the time, state constitutions endorsed separation of powers principles to sustain Whig legislative authority as "heirs to most of the prerogative powers taken away from the governors by the Revolution."22 Early state constitutions, for example, allowed legislatures to appoint governors, executive officers, and judges. $^{23}$ Separation of powers operated primarily as a restraint on the executive branches of government, designed to protect the legislature and, to a lesser extent, courts. ${ }^{24}$

When the Continental Congress was first created in 1774, it followed the Whig approach by attempting to carry out administrative tasks by delegating executive powers to committees of its own members. ${ }^{25}$ In early years, "Congress was primarily itself the executive, the administrator." ${ }^{26}$ But Congress eventually found it necessary to pass some aspects of governance off to the executive. ${ }^{27}$ The debate over the adoption of the Constitution revealed a more flexible, or mixed, understanding of separation of powers than Whig constitutionalism endorsed. Pubhus' constitutional design incorporated the notion of separation of powers. Madison wrote: "The accumulation of

20. See M.J.C. VILE, CONSTITUTIONALISM AND THE SEPARATION OF POWERS 35-36 (1967).

21. See DANiEl J. Elazar, THE AMERICAN CONSTITUTIONAL TradiTION 133 (1988). Elazar, a political scientist known for his writing on federalism, writes, "the Whig tradition placed great emphasis on direct, active, continuous, and well-nigh complete popular control over the legislature and government in general, through such devices as small electoral districts, short tenures of office, many elective offices, sharp separations of power, and procedures approaching constituent instruction of elected representatives." Id. at 109. See also DONALD S. LUTZ, POPULAR CONSENT AND POPULAR CONTROL: WHIG POLITICAL THEORY IN THE EARLY STATE CONSTITUTIONS 122 (1980) ("Whig political theory was, in fact, based upon legislative supremacy . . . "); Edward S. Corwin, The Progress of Constitutional Theory Between the Declaration of Independence and the Meeting of the Philadelphia Convention, 30 AM. HIST. REV. 511, 523-25 (1925) (discussing influence of Blackstone and Coke, who endorsed notions of legislative omnipotence, on Whig political theory).

22. WOOD, supra note 13 , at 162-63.

23. See id. at 155-56.

24. "When Americans in 1776 spoke of keeping the several parts of the government separate and distinct, they were primarily thinking of insulating the judiciary and particularly the legislature from executive manipulation." Id. at 157. See also LUTZ, supra note 21, at 122 ("[S]eparation of powers amounted to little more than a prohibition on multiple officeliolding, at least as far as the Whigs were concerned.").

25. See Jennings B. SANDERS, EVOlution of Executive Departments of the CONTINENTAL CONGRESS 1774-1789, at 4-5 (1935).

26. Charles C. Thach, JR., The Creation OF THE PResidency, 1775-1789: A STUdy IN CONSTITUTIONAL HISTORY 57 (photo. reprint 1969) (1923).

27. See LOUIS FISHER, THE POLITICS OF SHARED POWER 4-5 (4th ed. 1998). 
all powers legislative, executive and judiciary in the same hands, whether of one, a few or many, and whether hereditary, self appointed, or elective, may justly be pronounced the very definition of tyranny." ${ }^{28}$

However, in contrast to Whig notions of separation of powers, now championed by the Antifederalists, ${ }^{29}$ Madison argued for a flexible conception, one that allowed a single branch to exercise some of the powers of other branches:

The several departments of power are [not separated but] blended in such a manner as at once to destroy all symmetry and beauty of form, and to expose some of the essential parts of the edifice to the danger of being crushed by the disproportionate weight of the other parts. ${ }^{30}$

In contrast to the Antifederalist ideals of strict separation and legislative supremacy, ${ }^{31}$ the Federalists endorsed principles of mixed government, efficiency, and flexibility. ${ }^{32}$ Unlike the Antifederalists, the Federalists saw sovereignty as residing in "the People"-not the legislature-and imphicitly accepted that representatives of the People could reside in all three branches of government. ${ }^{33}$ The legislature, on such an understanding, no longer held the supreme authority that

28. THE FEDERALIST No. 47 (James Madison).

29. See WoOD, supra note 13, at 549-553 (describing Antifederalist separation of powers objections to the Constitution). The Antifederalists argued that Federalist separation of powers principles were poorly designed and were ineffective checks on government power. See Letter by An Officer of the Late Continental Army, PHILADElPHIA INDEP. GaZETTEer, Nov. 6, 1787, reprinted in 3 THE COMPLETE ANTI-FEDERALIST 91, 93 (Herbert J. Storing ed. 1981) (sevenvolume set). The Antifederahsts argued that separation of powers would be thwarted by the intertwined branches of government in the Constitution. For example, Cato wrote that the relations between the Senate and the President "will prevent either from being a check upon the other." Letters of Cato, N.Y.J., reprinted in 2 THE COMPLETE ANTI-FEDERALIST 123. For exam. ple, the Constitution authorizes the President to convene both houses of Congress and to veto legislation, which gives the executive power over the legislature, while it also grants the Senate some authority to act in an executive capacity. See, e.g., Letters from The Federal Farmer, in 2 The Complete ANTI-FEderalist 214; Essay by Montezuma, PhiladelPhIA INDeP. GazeTteer, Oct. 17, 1787, reprinted in 3 THE COMPLETE ANTI-FEDERALIST 53-54.

30. The Federalist No. 47 (James Madison). In Federalist Nos. 37 and 48, Madison further elaborated on the notion of sharing of power between the branches.

31. See JOHN A. ROHR, TO RUN A CONSTITUTION: THE LEGITIMACY OF THE ADMINISTRATIVE STATE 78 (1986) (noting that Antifederalists had "considerable difficulty grasping the theoretical foundation of the new Constitution" because it did not fit their principle of legislative suprem. acy); sources cited supra note 29 (quoting Cato, Federal Farmer, etc.).

32. The system was aptly captured in the words of Justice Robert H. Jackson: "While the Constitution diffuses power the better to secure hberty, it also contemplates that practice will integrate the dispersed powers into a workable government. It enjoins upon its branches separateness but interdependence, autonomy but reciprocity." Youngstown Sheet \& Tube Co. v. Sawyer, 343 U.S. 579, 635 (1952).

33. See Pushaw, supra note 10, at 411-25. 
Whig constitutionalism-and later Antifederalists-endorsed. ${ }^{34}$ The Federalist understanding of separation of powers ${ }^{35}$ is of contemporary relevance as a framework for organizing separation of powers principles applied by U.S. courts, including the nondelegation doctrine, and as a limitation on the unilateral exercise of legislative power.

\section{A. The Nondelegation Doctrine}

According to Article I of the U.S. Constitution "all legislative powers herein granted shall be vested in a Congress of the United States." Beyond this curt provision, the text of the U.S. Constitution does not expressly address the delineation of power between the legislative and executive branches. Yet federal courts have not shied away from developing a doctrine to assist in the interpretation of this constitutional provision.

Three decisions from the 1930s provide the Supreme Court's strongest statement of the nondelegation doctrine. In Panama Refining Co. v. Ryan, ${ }^{36}$ the Court held unconstitutional the section of the National Industrial Recovery Act that authorized the President "to prohibit the transportation in interstate and foreign commerce of petroleum ... in excess of the amount permitted to be produced or witlıdrawn from storage by any state law or valid regulation . . . ."37 According to Chief Justice Hughes, "Congress has declared no policy, has estabhshed no standard, has laid down no rule. . . . If $\S 9$ (c) were held valid, it would be idle to pretend that anything would be left of limitations upon the power of the Congress to delegate its law-making function." ${ }^{38}$ A.L.A. Schechter Poultry Corp. v. United States ${ }^{39}$ invali-

34. Indeed, Madison and others exphcitly warned of the legislative excess of Whig constitutionalism. Madison was reminded of "a tendency in our governments to throw all power into the Legislative vortex. The Executives of tlue States are in general little more than Cyphers; the legislatures omnipotent." 2 THE RECORDS OF THE FEDERAL CONVENTION OF 1787, at 35 (Max Farrand, ed., 1911) (4 vols.). James Wilson predicted that, without checks, the "natural operation of the Legislature will be to swallow up the Executive...." 1 id. at 107. Others, such as Governeur Morris and John Mercer, also made efforts to highlight legislative aggrandizement and usurpation. See 2 id. at $52 ; 2$ id. at 298.

35. That Federalists disavowed legislative supremacy and believed in basic notions of blended or sliared powers slould not suggest agreement among all Federalists on separation of powers issues. Madison and Hamilton, for example, disagreed on whether executive powers were inherent or must be given by Congress. See JOHN P. ROCHE \& LEONARD W. LEVY, THE PRESIDENCY 10-12 (1964); James Willard Hurst, Alexander Hamilton, Law Maker, 78 ColUM. L. REV. 483, 500.05 (1978); see also LEONARD D. WHITE, THE FEDERALISTS: A STUDY IN ADMINISTRATIVE HISTORY 1789-1801 (1948).

36. Panama Refining Co. v. Ryan, 293 U.S. 388 (1935).

37. Id. at 406 (quoting National Industrial Recovery Act of 1933, § 9, 15 U.S.C. $\S 709$ (c).

38. Id. at 430.

39. A.L.A. Schechter Poultry Corp. v. United States, 295 U.S. 495 (1935). 
dated another provision of the same statute-this a more sweeping delegation to the President to adopt "codes of fair competition" ${ }^{10}$ on similar grounds. A third case, Carter v. Carter Coal Co., invalidated a federal statute providing that maximum hours and minimum wages agreed upon by a majority of miners and mine-operators would be binding on the industry. ${ }^{41}$ Stressing the peculiar dangers of delegation to private actors, the Court observed that such a delegation "is not even delegation to an official or an official body, presumptively disinterested, but to private persons whose interests may be and often are adverse to the interests of others in the same business." 42 The classic doctrine, as expressed in Panama Refining, Schechter, and Carter Coal, invalidated legislation based on a lack of a substantive, "intelligible principle" articulated by Congress to evaluate an agency's compliance with a statute. ${ }^{43}$

The doctrine was only invoked briefly during the 1930s. Since 1935 , the Supreme Court has not invalidated a single statute on nondelegation grounds. By 1958, when Kenneth Culp Davis published the first version of his Administrative Law Treatise, he concluded: "Congress may and does lawfully delegate legislative power to administrative agencies. Lawyers who try to win cases by arguing that congressional delegations are unconstitutional almost invariably do more harm than good to their clients' interests." ${ }^{44}$ Largely as a critique of the approach of states to nondelegation, Davis urged against federal courts scrutinizing the breadth of delegated discretion in statutory standards; instead, he suggested that courts look for procedural safeguards-agency rulemaking procedures and the like-as a means of limiting agency discretion. ${ }^{45}$ In result, if not in apphication, the post-New Deal federal courts can be said to have eventually followed Davis' approach. ${ }^{46}$

40. Justice Cardozo, who had dissented in Panama Refining, concurred in Schechter, noting that this delegation created a "roving commission" that went far beyond the earlier case before the court. Id. at 551-52 (Cardozo, J., concurring).

41. Carter v. Carter Coal Co., 298 U.S. 238 (1936).

42. Id. at 311 .

43. See, e.g., J.W. Hampton, Jr., \& Co. v. United States, 276 U.S. 394, 409 (1928) ("ח]f Congress shall lay down by legislative act an intelligible principle to which the person or body authorized to [regulate] is directed to conform, such legislative action is not a forbidden delegation of legislative power").

44. 1 KENNETH CULP DAVIS, ADMINISTRATIVE LAW TREATISE $\$ 2.01$, at 75 (1st ed. 1958).

45. See id. \$2.15, at 151; see also KENNETH CULP DAVIS, DISCRETIONARY JUSTICE 220-30 (1969); Davis, supra note 11, at 725-30.

46. See, e.g., Amalgamated Meat Cutters \& Butcher Workmen v. Connally, 337 F. Supp. $737,758.60$ (D.D.C. 1971) (observing that the safeguard of judicial review and administrative 
Adherence to a weak nondelegation doctrine is compatible with Federalist separation of powers principles. As Jerry Mashaw has suggested, delegation to agencies has functional advantages. First, delegation to agencies can assist in reducing the costs of making decisions, including the monitoring and supervision costs; agencies have institutional advantages over legislatures that make them more cost effective. ${ }^{47}$ Second, Mashaw observes, delegation can make decisionmaking more democratic to the extent it enhances the responsiveness of political decisions to the desires of the general electorate througl accountability to the President, who is more responsible than the legislature to diversity in voter preferences and better able to avoid voting cycles. ${ }^{48}$ The prodelegation argument, endorsed by Mashaw and others, ${ }^{49}$ is compatible with Federalist separation of powers principles to tlie extent it depends on a flexible or mixed notion of eacli branch's power and urges, as did Madison, that democracy not be equated with simple majoritarianism. ${ }^{50}$

Yet the prodelegation position has not gone without criticism, both academic and judicial. Theodore Lowi, writing in the 1960s, characterized the placement of governmental authority in the hands of bureaucrats as a governmental failure. Congress's failure to give a clear and specific pohicy direction, according to Lowi, results in "an imposition of impotence." 51 Since administrators are unable to produce the general statements of policy to establish new directions for regulatory programs, they are only able to use their delegated powers to respond in a piecemeal, ad hoc way to interest groups, violating notions of representative governance. In the early 1980s, Peter Aranson, Ernest Gellhorn, and Glen Robinson grounded these arguments in the public choice literature, suggesting the delegation of congressional authority to agencies is structurally incompatible witl the proper

procedures is a primary function of the nondelegation doctrine); see also Richard B. Stewart, Beyond Delegation Doctrine, 36 AM. U. L. REV. 323, 323 (1987).

47. See JerRy L. MashaW, Greed, ChaOs, AND Governance: USING PUblic Choice to IMPROVE PUBLIC LAW 148-52 (1997) [hereinafter MASHAW, GREED, CHAOS, AND GOVERNANCE]; see also generally Jerry L. Mashaw, Prodelegation: Why Administrators Should Make Political Decisions, 1 J.L. ECON. \& ORG. 81 (1985) [hereinafter Mashaw, Prodelegation].

48. See MASHAW, GREed, ChaOS \& GOVERNANCE, supra note 47 , at 152-56.

49. See, e.g., Dan M. Kahan, Democracy Schmemocracy, 20 CARDozo L. REv. 795 (1999); Peter H. Schuck, Delegation and Democracy: Comments on David Schoenbrod, 20 CARDOZo L. REV. 775 (1999); Harold J. Krent, Delegation and Its Discontents, 94 CoLUM. L. REV. 710, 722-23 (1994) (book review).

50. For additional historical support for executive-led administration in Federabst doctrine and elsewhere, see generally RoHR, supra note 31, at 76-89; John A. Rohr, Public Administration, Executive Power, and Constitutional Confusion, 49 PUB. ADMIN. REV. 108 (1989).

51. See THEODORE J. LOWI, THE END OF LIBERALISM: IDEOLOGY, POLICY, AND THE CRISIS OF PUBLIC AUTHORITY 156 (1969). 
functioning of separation of powers. ${ }^{52}$ David Schoenbrod, writing in the late 1980s and early 1990s, echoed these concerns, calling for the Supreme Court to rein in congressional delegations of power to agencies by reviving the nondelegation doctrine. ${ }^{53}$

In the 1980s Justice Rehnquist attempted to revive the classic doctrine beginning with his concurrence in Industrial Union Department $v$. American Petroleum Institute. ${ }^{54}$ There he stated the case for strong enforcement of the nondelegation doctrine:

\footnotetext{
First, and most abstractly, it ensures to the extent consistent with orderly governmental administration that important choices of social policy are made by Congress, the branch of our Government most responsive to the popular will. Second, the doctrine guarantees that, to the extent Congress finds it necessary to delegate authority, it provides the recipient of that authority with an "intelligible principle" to guide the exercise of the delegated legislative discretion. Third, and derivative of the second, the doctrine ensures that courts cliarged with reviewing the exercise of delegated discretion will be able to test that exercise against ascertainable standards. ${ }^{55}$
}

In his dissent to American Textiles Manufacturers Institute, Inc. $v$. Donovan, Justice Rehnquist more explicitly called for a revival of the nondelegation doctrine. ${ }^{56}$

Although, following Justice Rehnquist's suggestion, some lower courts referred to the doctrine as "no longer ... moribund," search far and wide to find lower court opinions striking delegations as unconstitutional. There are recent examples. A 1995 Eighth Circuit case, South Dakota v. United States Department of Interior, ${ }^{58}$ found statutory language authorizing the Secretary of Interior to acquire any interest in land "for the purpose of providing land for Indians" 59 an unconstitutional delegation of legislative authority. A 1999 D.C. Circuit panel invoked the nondelegation doctrine as a reason for

52. See generally Peter H. Aranson, et al., A Theory of Legislative Delegation, 68 CoRNELL, L. REV. 1 (1982).

53. See generally DAVID SCHOENBROD, POWER WITHOUT RESPONSIBILITY: HOW CONGRESS ABuses the People Through Delegation (1993); David Schoenbrod, Delegation and Democracy: A Reply to my Critics, 20 CARDOZO L. REV. 731 (1999).

54. Industrial Union Dep't v. American Petroleum Inst., 448 U.S. 607, 685-86 (1980) (Rehnquist, J., concurring).

55. Id. at 685.86 (citations omitted).

56. American Textiles Mfg. Inst. Inc. v. Donovan, 452 U.S. 490, 547 (1981) (Rehnquist, C.J., dissenting).

57. See, e.g., Fort Worth \& Pac. Ry. v. Lewis, 693 F.2d 432, 435 n.8 (5th Cir. 1982).

58. South Dakota v. United States Dep't of Interior, 69 F.3d 878, 884-85 (8th Cir. 1995), vacated, 519 U.S. 919 (1996).

59. 25 U.S.C. $§ 465$ (1999). 
reversing the Environmental Protection Agency's interpretation of the scope of its authority to set ambient air quality standards under the Clean Air Act. ${ }^{60}$ While the D.C. Circuit panel drew on the rhetoric of nondelegation, it did not strike down the statutory provision but only the EPA's reading of it; ${ }^{61}$ thus, this case was decided more on statutory interpretation than nondelegation grounds. But federal cases invoking nondelegation are very rare and do not appear to be supported by the Court's recent cases. ${ }^{62}$ Thus, despite the criticisms of scholars and Justice Rehnquist-as well as the handful of heretical opinions by lower courts, such as the Eighth Circuit-today it is well recognized that, in the federal system, limits on delegation are either nonexistent or underenforced.

\section{B. INS v. Chadha: Judicial Invalidation of the Legislative Veto}

It should come as no surprise that the United States Congress often seeks ways to oversee agency discretion that maximize the legislature's degree of control. Congress has a variety of tools at its disposal to do this; among them are the drafting of statutes, the power of appropriation, legislative review of executive appointments and removals, committee oversight of agency decisionmaking, and the legislative veto. ${ }^{63}$ Although separation of powers jurisprudence has something to say about each of these, this Article focuses on its apphcation to the legislative veto.

The legislative veto is often referred to as a type of "rules review"-a way, outside of seeking review in a court or enacting legislation, for a legislature to check agency rulemaking for rationality, costeffectiveness, consistency, and fair process. ${ }^{64}$ The veto grew from the pohtical science of Woodrow Wilson, who looked with skepticism on the ability of the American tripartite constitutional structure to effectively accommodate the growth of bureaucracy in the executive branch and sought to introduce pro-parliamentary reforms to the U.S.

60. See American Trucking Ass'n Inc. v. EPA, 175 F.3d 1027, 1037-38 (D.C. Cir. 1999).

61. See id. at 1038.

62. Kenneth Culp Davis and Richard J. Pierce characterize the Court as abandoning its interest in reviving the nondelegation doctrine, evidenced by recent cases upholding delegations including Mistretta v. United States, 488 U.S. 361 (1989) (delegation to an independent agency), Skinner v. Mid-America Pipeline Co., 490 U.S. 212 (1989) (delegation to executive agency), and Touby v. United States, 500 U.S. 160 (1991) (delegation to Attorney General). See 1 KENNETH CUlP DAvis \& RICHARD J. PIERCE, JR., ADMINISTRATIVE LAAW TREATISE 76, § 2.6, at 83-85 (3d ed. 1994).

63. See FISHER, supra note 27, at 68 .

64. Rules review, often institutionalized in state legislatures, is discussed further infra Part III.C. 
constitutional structure.65 The legislative veto-"one of the most highly touted" Wilsonian reforms to the U.S. constitutional structurewas enacted into law in the Reorganization Act of 1932 but did not begin to attract widespread attention until the 1960 s and 1970 s. $^{66}$

As a policy tool, the legislative veto allows a legislature to delegate decisionmaking authority to administrative agencies while also retaining some ability to reject agency proposals. Legislative vetoes do not generally require legislatures to give specific reasons for rejecting the agency actions, but allow rejection of an agency's proposal by a straight up or down vote of one or both chambers or by a legislative committee. ${ }^{67}$

Nearly fifty years after establishment of the veto, in the early 1980s, the U.S. Supreme Court rejected the one-house legislative veto and effectively held that concurrent resolution veto is also unconstitutional. In INS v. Chadha, the Court declared that the legislative veto provision of section 244 of the Immigration and Nationality Act is unconstitutional. ${ }^{68}$ The majority opinion, written by Chief Justice Burger, concluded that the one-house legislative veto provisions of the statute failed to satisfy the bicameralism and presentment to the President requirements in Article I, Section 7 of the U.S. Constitution. The Court reasoned that the legislative veto was "legislative" in its character and effect because it altered "the legal rights, duties, and relations of persons ... outside the Legislative Branch."69 The opinion was important, making front page headlines, because it effectively invalidated hundreds of legislative vetoes in federal statutes since the legislative veto had first been enacted into law in the Reorganization Act of $1932 .^{70}$

As a constraint on rules review, separation of powers is seen by many participants in the pohitical process as an effort to reduce access to the agency rulemaking process, and hence as undemocratic in its enforcement as a constitutional norm. Woodrow Wilson's pohtical science, which viewed the legislative body as the supreme lawmaker in our democracy, lends historical support to these critics of the doc-

65. See generally WOODROW WILSON, CONGRESSIONAL GOVERNMENT: A STUDY IN AMERICAN POLITICS (Peter Smith ed. 1956) (1885).

66. See JESSiCA KORN, THE POWER OF SEPARATION: AMERICAN CONSTITUTIONALISM AND THE MYTH OF THE LEGISLATIVE VETO 4-5 (1996).

67. This avoids the normal legislative process in which the executive would have veto power over the legislature's attempts to statutorily prevent an agency action.

68. INS v. Chadha, 462 U.S. 919,959 (1983).

69. Id. at 952 .

70. See KORN, supra note 66, at 5-6. 
trine. For Wilson and other critics of rigid application of separation of powers principles, the new problems posed by twentieth century democracy demand flexible solutions, and thus may require the relaxation of separation of powers principles to facilitate creative approaches to problems by the legislature. ${ }^{71}$ This view found expression in Justice White's Chadha dissent, ${ }^{72}$ which critiqued the formalism of the majority opinion. According to Justice White, the legislative veto

has become a central means by which Congress secures the accountability of executive and independent agencies. Without the legislative veto, Congress is faced with a Hobson's choice: either to refrain from delegating the necessary authority, leaving itself with a hopeless task of writing laws with the requisite specificity to cover endless special circumstances across the entire pohicy landscape, or in the alternative, to abdicate its law-making function to the executive branch and independent agencies. To choose the former leaves major national problems unresolved; to opt for the latter risks unaccountable policymaking by those not elected to fill that role. ${ }^{73}$

Justice White would have upheld the legislative veto of legislative or quasi-legislative action as consistent with the purposes of Article I and separation of powers principles. ${ }^{74}$ Instead of endorsing the majority's view that separation of powers implements a "hermetic sealing off of the three branches of Government from one another,"75 Justice White urged a balance of powers to effectuate the accommodation and practicality necessary for effective governance. ${ }^{76}$

Although Chadha's status as law has not been called into serious question since it was decided, there has been no dearth of criticism of the opinion and its formalism. ${ }^{77}$ To achieve some of the objectives of the legislative veto without violating Chadha's rule, Congress recently adopted a formal mechanism for review of major agency rules-known as "joint resolution disapproval."78 Also, from

71. See generally WILSON, supra note 65.

72. Chadha, 462 U.S. at 967 (White, J., dissenting).

73. Id. at 967-68.

74. His dissent recognizes limits on the legislative veto to the extent it is used as a check on inherently executive functions, such as initiating prosecutions. See id. at 1002.

75. Id. at 999 (quoting Buckley v. Valeo, 464 U.S. 1, 121 (1976)).

76. See id.

77. See generally KORN, supra note 66; E. Donald Elliott, INS v. Chadha: The Administrative Constitution, the Constitution, and the Legislative Veto, 1983 SUP. CT. REV. 125; Peter M. Shane, The Separation of Powers and the Rule of Law: The Virtues of "Seeing the Trees," 30 WM. \& MARY L. REV. 375 (1989); Peter L. Strauss, Was There a Baby in the Bathwater? A Comment on the Supreme Court's Legislative Veto Decision, 1983 DUKE L.J. 789; Laurence Tribe, The Legislative Veto Decision: A Law By Any Other Name?, 21 HARV. J. ON LEGIS. 1 (1984)

78. See Daniel Cohen \& Peter L. Strauss, Congressional Review of Agency Regulations, 49 ADMIN. L. REV. 95, 97 (1997); Michael Herz, The Legislative Veto in Times of Political Reversal: Chadha and the 104th Congress, 14 CONST. COMMENTARY 319, 319 (1997). 
time to time general reform proposals surface that would clearly violate Chadha's rule, ${ }^{79}$ but none of these have been adopted into law.

Less obvious than those general reforms that clearly would violate Chadha's rule, Congress has continued to place legislative vetoes in subject-matter specific bills signed into law by the President. From the day that Chadha was issued through the end of 1997, Congress has enacted more than four hundred legislative vetoes. ${ }^{80}$ In addition, Congress appears to have driven the legislative veto underground, relying on informal understandings with the executive branch to perpetuate express congressional acquiescence in agency policy decisions. An example is the dispute that erupted in 1987 between James Miller, III, the Director of the Office of Management and Budget, and the House Appropriations Committee. ${ }^{81}$ When Miller objected on Chadha grounds to a provision that required the Administration to obtain "written prior approval" from the Appropriations Committee before transferring foreign assistance funds from one account to another, the Committee advised him that Congress would repeal the legislative veto but also take away the Administration's authority to transfer foreign assistance funds. ${ }^{82}$ A couple of years later, the two branches finally reached a compromise when Congress removed the legislative veto from the public law but required the Administration to follow "the regular notification procedures of the committees on Appropriations" before transferring funds. ${ }^{83}$ While these procedures did not appear in the public law, they required the Administration to notify committees of each transfer and provided a 15-day waiting period during which the committees could object. ${ }^{84}$ Although committee objection had no legal effect, if the Administration ignored objections it proceeded at its peril and would likely lose its transfer authority. ${ }^{85}$ Because Congress wields the heavy stick of budget and lawmaking powers over executive branch agencies, infor-

79. See Stephen Gold, Welcome to the rule of rules, WASHINGTON TIMEs, May 27, 1997, at A19 (describing present legislative proposal to require agencies to send proposed rules to Congress for an up or down vote).

80. See FISHER, supra note 27, at 102.

81. See Fishér, supra note 27, at 99-104; see also LOUIS FISHER \& NEAL DEVINS, POLITICAL DYNAMICS OF CONSTITUTIONAL LAW 129 (1992).

82. See FISHER \& DEVINS, supra note 81, at 129-30.

83. Foreign Operations, Export Financing, and Related Programs Appropriations Act, 1990, Pub. L. No. 101-167, §514, 103 Stat. 1195, 1219 (1990). 30 .

84. See FISHER, supra note 27, at 99-104; see also FISHER \& DEVINS, supra note 81, at 129-

85. See supra note 84. 
mal committee vetoes continue to survive in many subject-matter specific contexts at the federal level. ${ }^{86}$

\section{Connecting the Two Strands: The Convergence of Rationales for Separation of Powers}

Whig and Antifederalist approaches to separation of powers, reacting to the concentration of power in the hands of the monarchy and colonial governors, invoked separation of powers principles to protect against the concentration of executive power. By contrast, the Federalists invoked separation of powers doctrines to protect against the untutored masses, particularly as these masses found expression in unbridled legislative power. The Federalists thus invoked a more mixed conception of separation of powers, one that worked to limit legislative supremacy. In addition, while the protection of liberty against encroachment by government is one of the predominant rationales for separation of powers, ${ }^{87}$ the efficiency rationale of the Federalists should not be forgotten. Separation of powers, according to the views of many Federalists, fosters governmental efficiency by assigning numerous tasks to designated authorities without risking interference by other branches. ${ }^{88}$

In addition, it has been observed that the Federalist account of separation of powers fosters representation and accountability in government. It enhances representation to the extent that the domination of one branch of government by a single party, or faction, becomes of less significance in the overall lawmaking process. It enhances accountability to the extent that it encourages the various branches of government to take responsibility for decisions, rather than attempting to pass the buck to another branch with so many strings attached that the branch is unable to act independently but must risk taking the blame for bad decisions.

Accountability, representation, and efficiency lay at the core of Federalist separation of powers principles, and to this effect the constitutional norm retains its relevance even as government has ex-

86. As Michael Fitts warns, informal micropolitical factors would advise against overexaggerating the role of formal strncture. See Michael A. Fitts, The Foibles of Formalism: Applying a Political "Transaction Cost" Analysis to Separation of Powers, 47 CASE W. RES. L. REV. 1643, 1645-56 (1997).

87. See supra note 19 and accompanying text (discussing Montesquieu); Rebecca L. Brown, Separated Powers and Ordered Liberty, 139 U. PA. L. REV. 1513, 1513-14 (1991).

88. See Louis Fisher, The Efficiency Side of Separated Powers, 5 J. AM. STUD. 113, 129-31 (1971); William C. Banks, Efficiency in Government: Separation of Powers Reconsidered, 35 SYRACUSE L. REV. 715, 718-23 (1984). 
panded far beyond the expectations of our founders. Federal courts interpret the two strands of separation of powers affecting agency rulemaking to endorse an essentially prodelegation position-encouraging legislatures to delegate to agencies when they expect the delegation to be welfare enhancing, while discouraging them from delegating where they cannot trust agencies to regulate responsibly without strings, such as the legislative veto, attached.89 This approach to interpreting separation of powers principles is compatible with the spirit of the Federalist doctrine, but is incompatible with the Antifederalist ideal of legislative supremacy.

At its simplest doctrinal level, the federal approach suggests weak enforcement of the nondelegation doctrine and strong enforcement of limitations on legislative oversight. Delegation, it has been observed, has positive welfare implications and may be necessary to promote efficiency and flexibility in governance, consistent with the Federahist spirit. To the extent there are limits on delegation, it will be very difficult for courts to articulate certain standards for measuring which delegations pass constitutional muster. By failing to enforce the nondelegation doctrine, federal courts allow for benefits of delegation without placing the courts in the awkward position of developing standards for enforcement. While compatible with Federalist ideals of shared power and efficiency, a weak nondelegation doctrine thwarts the Antifederahist ideals of strict separation and legislative supremacy.

At the same time, federal courts since Chadha have interpreted separation of powers principles to imply some limits on legislative oversight. Harold Bruff and Ernest Gellhorn, writing before Chadha, observed that the presence of a legislative veto may encourage irresponsible delegation by Congress. Since with the legislative veto Congress holds the hope of checking agency pohicy at the implementation stage, this power encourages Congress to make more sweeping delegations than it otherwise would..$^{90}$ Effectively, Chadha may act as an indirect nondelegation doctrine by creating incentives against delegation by the legislature. After Chadha, Congress must be willing to part with the power to veto administrative action before

89. On the merits of the prodelegation position, see MASHAW, GREED, CHAOS, AND GOVERNANCE, supra note 47, at 131-57.

90. See Harold H. Bruff \& Ernest Gellhorn, Congressional Control of Administrative Regulation: A Study of Legislative Vetoes, 90 HARV. L. REV. 1369, 1427 (1977). 
it delegates authority to an administrative agency. ${ }^{91}$ Without the strong degree of control provided by a legislative veto, as legislators face a decision whether to delegate authority to an administrative agency they will consider the importance of and ability to engage in other types of oversight of agency decisionmaking. With respect to some issues, legislators may decide continued legislative control of agency rulemaking is not important. However, with respect to many issues, legislative control may remain an important mechanism to legislators in making their decision to delegate. To the extent Chadha places limits on the ability of the Congress to engage in control with the legislative veto, it acts as a disincentive against delegation without requiring courts to step in and articulate standards for measuring nondelegation. To this extent, the two strands of separation of powers, though seemingly prodelegation, may be in tension. Nevertheless, any tension that exists between the two strands in the federal system is probably of minor concern in practice. The fact that since Chadha the United States Congress lias continued to engage in sweeping delegations of authority to agencies suggests that the disincentive against delegation is probably not strong enough to achieve the same result as reinvigorating the nondelegation doctrine, as Schoenbrod and many otler critics recommend.

Chadha's formalism eschews the notions of mixed government endorsed in Federalist separation of powers principles. But Chadha's result-invalidation of the legislative veto and a reduction of unilateral control over executive decisions-may promote Federalist goals to the extent it encourages more responsible and accountable delegation and works to limit legislative supremacy over bureaucracy. Thus, Chadha is consistent with the Antifederalist strict separation ideal, but is inconsistent with the Antifederalist notion of legislative supremacy.

\section{SeParation OF POWERS AS A CONSTRAINT ON STATE AGENCY RULEMAKING}

Separation of powers doctrines at the state level affect the quality of governance that state agencies are able to deliver to their

91. See Harold J. Krent, Fragmenting the Unitary Executive: Congressional Delegations of Administrative Authority Outside the Federal Government, 85 NW. U. L. REV. 62, 75-77 (1990); Harold J. Krent, Separating the Strands in Separation of Powers Controversies, 74 VA. L. REv. 1253, 1282-83 (1988); Strauss, supra note 77, at 809-12. Cf. SOTIRIOS A. BARBER, THE CONSTITUTION AND THE DELEgation OF CONGRESSIONAL POWER 109 (1975) (observing that techniques of "legislative oversight in some manner provide substitutes for congressional adherence to the principles of nondelegation"). 
citizens. To the extent agencies at the state level are unable to deliver important programs, the demand for federal regulation may increase. Thus state separation of powers doctrine, by influencing the size of the federal government, may unintentionally affect the balance of powers between the federal and state governments.

Despite the Federalist views of separation of powers, the U.S. Constitution fails to dictate a specific form of separation of powers for state governments. According to the Guarantee Clause of the Constitution, "[t]he United States shall guarantee to every State in this Union a Republican Form of Government. . .."92 Although one might argue that this requires some minimal level of separation of powers in the states, ${ }^{93}$ the clause has been held enforceable only by Congress rather than by the federal courts; ${ }^{94}$ at best, the U.S. Constitution speaks in a "whisper" to separation of powers in the states. ${ }^{95}$ Thus, to the extent separation of power principles apply at all to the states, they emanate primarily from state constitutional law, not from the U.S. Constitution.

Separation of powers principles were contained in state constitutions at the time of the Articles of Confederation and continue to play an important role as state courts attempt to define the relationship between the legislature and the administrative state. Unlike the U.S. Constitution, which does not exphcitly address separation of powers, most state constitutions contain explicit separation of powers clauses. The texts of these clauses, however, do not predict the outcomes of state judicial opinions.

92. U.S. CONST. art. IV, $\S 4$.

93. See, e.g., Fox v. McDonald, 13 So. 416, 420 (Ala. 1893) (noting that the guarantee of a republican form of government vests the power of selecting governmental officers in the people, and that the power to appoint to office is not an inherently executive function); see also Michael C. Dorf, The Relevance of Federal Norms for State Separation of Powers, 4 RoGer WILliams U. L. REV. 51, 52 (1998) (arguing that some measure of separation of powers in state government is a structural requirement of the U.S. Constitution and that the Guaranty Clause is the best textual source for this requirement); Marc E. Elkins, Comment, Treatment of the Separation of Powers Doctrine in Kansas, 29 U. KAN. L. REV. 243, 246-48 (1981) (discussing framers' intent regarding Guarantee Clause and separation of powers doctrine at the state level).

94. See Pacific States Tel. \& Tel. Co. v. Oregon, 223 U.S. 118, 133, 137 (1912) (Congress's determination of whether a particular state government's form is "republican" in form is binding on every other department of government); Luther v. Borden, 48 U.S. (7 How.) 1, 42 (1849) (determination of whether a particular state government is "republican" is for Congress, not the courts). But see Dorf, supra note 93, at 67 (arguing that Guaranty Clause claims may be justiciable in state court); Deborah Jones Merritt, The Guarantee Clause and State Autonomy: Federalism for a Third Century, 88 COLUM. L. REV. 1, 2 (1988) (arguing that Guarantee Clause could be used to set some minimum degree of autonomy for states against federal regulation).

95. See Dorf, supra note 93, at 77 (noting that the U.S. Constitution forecloses "only those arrangements deeply offensive to principles of representative government"). 
Administrative law scholars in the 1960s described a general trend in the states towards upholding broad delegations when procedural safeguards, or other minimal protections, are in place to protect against the arbitrary exercise of executive power. ${ }^{96}$ However, despite the predictions of 1960 s and 1970s scholars, in the states, unlike the federal system, the nondelegation doctrine is alive and well in the late 1990s. Many states require the legislature to provide specific standards to guide agency discretion in the statute delegating authority to an agency. Although some states endorse Davis' safeguards approach, favoring broad delegation to administrative agencies, most states reject it. This departs from the approach of most federal courts in interpreting separation of powers principles affecting the nondelegation doctrine. ${ }^{97}$

As in the federal system, in most state systems separation of powers works to constrain legislative control over the executive. In many state administrative processes, rules review is an active part of the rulemaking process, much more integral to agency rulemaking process than at the federal level..$^{98}$ Separation of powers may limit the power of legislatures to delegate rulemaking authority to agencies with strings attached that allow legislative oversight without engaging the full constitutional lawmaking process. In addition, "take care" clauses may limit a legislature's ability to interfere with agency rulemaking. Yet, as I sliall argue, enforcement of this separation of powers principle by state courts is weaker than at the federal level.

Although many describe state courts as adopting a deferential position towards, and rarely deviating from, federal constitutional doctrine,,$^{99}$ in the separation of powers context the approach of many state courts, echoing Antifederalist ideals, contrasts starkly with the approach of federal courts. The approacl of state courts to interpreting these doctrines appears to transcend constitutional text.

96. See 1 FranK E. COOPER, State AdMINISTRATIVE LAW 81 (1965); see also KenNETH CULP DAVIS, ADMINISTRATIVE LAW TREATISE § 3.01, at 149 (2d ed. 1978).

97. This is not inconsistent with what Davis described in the 1950s, when he observed "numerous delegations by state legislatures have been invalidated, and the non-delegation doctrine in the state courts continues to have a good deal of force during the nineteen-fifties." 1 DAVIS, supra note $44, \S 2.07$, at 101 .

98. An overview is provided in NATIONAL ASSOCIATION ON ADMINISTRATIVE RULES REVIEW, 1996-97 ADMINISTRATIVE RULES REVIEW DIRECTORY AND SURVEY (1996) [hereinafter NAARR]. Examples are discussed infra, at Part III.C.

99. See Ronald K.L. Collins \& Peter J. Galie, Models of Post-Incorporation Judicial Review: 1985 Survey of State Constitutional Individual Rights Decisions, 55 U. CIN. L. REv. 317, 332-39 (1986); Peter J. Gahie, Modes of Constitutional Interpretation: The New York Court of Appeals' Search for a Role, 4 EMERGING ISSUES IN ST. CONST. L. 225, 226 (1991). See also BARRY LATZER, STATE CONSTITUTIONS AND CRIMINAL JUSTICE 158 (1991) (estimating that, in criminal law decisions, state courts deviate from federal doctrine in less than one-third of their cases). 


\section{A. Separation of Powers Provisions in State Constitutions}

Separation of powers is a bedrock principle to the constitutions of each of the fifty states. Since the time of the founding, most state constitutions have expressly acknowledged separation of powers principles in their constitutional texts. ${ }^{100}$ The language of state separation of powers clauses has its origin in the Virginia, Maryland, North Carolina, Georgia, and Massachusetts constitutions in existence during debates over adoption of the U.S. Constitution. ${ }^{101}$ The Virginia Constitution of 1776 , the first to make separation of powers a statement of positive law, contained a provision requiring " $[\mathrm{t}]$ hat the Legislative and Executive powers of the State should be separate and distinct from the Judicative."102 The Massachusetts Constitution of 1780 endorsed a separation of powers provision stating:

In the government of this Commonwealth, the legislative department shall never exercise the executive and judicial powers, or either of them: The executive shall never exercise the legislative and judicial powers, or either of them: The judicial shall never exercise the legislative and executive powers, or either of them: to the end it may be a government of laws and not of men. ${ }^{103}$

Modern state constitutions borrow from the tradition established by these early constitutions. Separation of powers principles are expressed in three basic approaches in the texts of state constitutions.

The overwhelming majority of modern state constitutions contain a strict separation of powers clause. This clause is strict to the extent it not only divides power between the various branches but also instructs that one branch is not to exercise the powers of any of the others, much as the Massaclusetts Constitution of 1780 . For example, Florida's Constitution states:

The powers of the state government shall be divided into legislative, executive and judicial branches. No person belonging to one branch shall exercise any [of the] powers appertaining to either of the other branches unless expressly provided herein. 104

100. See WoOD, supra note 13 , at 150-61.

101. See Bernard Schwartz, Curiouser and Curiouser: The Supreme Court's Separation of Powers Wonderland, 65 NOTRE DAME L. REV. 587, 588 (1990).

102. Id.

103. This provision was contained in Massachusetts' Declaration of Rights. See id. at 58889.

104. FLA. CONST. art. II, §3. 
While this language seems strong, Florida is not unique. Thirty-five states have such clauses in their constitutions. ${ }^{105}$

A general separation of powers clause, by contrast, simply divides the powers of government into three branches, without prohibiting one branch from exercising the power of another. An example is North Carolina's Constitution, which states: "The legislative, executive and supreme judicial powers of the State government shall be forever separate and distinct ...."106 Five states have general separation of powers clauses. ${ }^{107}$

In each of the remaining ten states, there is no explicit separation of powers clause in the state constitution. In these states, separation of powers is inferred from the allocation of powers to each of the branches of government, in a manner similar to its inference from the allocation of power among the branches in the U.S. Constitution.

\section{B. State Approaches to Nondelegation}

A constitutional text provides only a context for interpretation and application of separation of powers principles by state courts. Not surprisingly, among state courts, there is a diversity of approaches towards interpreting separation of power provisions for nondelegation purposes. ${ }^{108}$ The approaches of the state courts vary, even where constitutional texts are sometimes similar or identical.

\section{1. "Weak" Nondelegation States}

A handful-and only a handful-of states follow the Davis "procedural safeguards" approach, upholding legislative delegations as long as the agency has adequate procedural safeguards in place. For example, in Barry and Barry, Inc. v. Department of Motor Vehicles,

105. See ALA. CONST. art. III $\S \S 42,43$; ARIZ. CONST. art. III; ARK. CONST. art. $4 \S \S 1$, 2; CAL. CONST. art. 3, § 3; COLO. CONST. art. 3; FLA. CONST. art. 2, § 3; GA. CONST. art. I, § 2, \$3; IDAHO CONST. art. II, § 1; ILL. CONST. art. 2 , § 1; IND. CONST. art. 3, § 1; IOWA CONST. art. 3 , § 1; KY. CONST. $\S \S 27,28$; LA. CONST. art. 2, $\S 1,2$; ME. CONST. art. 3, $\S 1,2$; MD. CONST. art. 8; MASS. CONST. pt. I, art. 30; MICH. CONST. art. 3, § 2; MINN. CONST. art. 3, § 1 (amended 1974); MISS. CONST. art. $1, \S \S 1,2$; Mo. CONST. art. 2, § 1; MONT. CONST. art. III, $\S 1$; NEB. CONST. art. II, § 1; NEV. CONST. art. $3, \S 1$; N.J. CONST. art. 3, 1 1; N.M. CoNST. art. 3 , § 1; OKLA. CoNST. art. 4, § 1; OR. CONST. art. III, § 1; S.C. CONST. art. I, § 8; TENN. CONST. art. 2, §§ 1, 2; TEX. CONST. art. 2, § 1; UTAH CONST. art. 5, § 1; VT. CoNST. chap. II, § 5; VA. CoNST. art. III, § 1; W. VA. CONST. art. 5, § 1; WYO. CoNST. art. $2, \S 1$.

106. N.C. CoNST. art. I, $\S 6$.

107. See CONN. CONST. art. 2; N.H. Const. pt. I, art. 37; N.C. CONST. art. I, § 6; R.I. CONST. art. 5 (discussing amendments); S.D. CoNST. art. II.

108. An earlier survey is Gary J. Creco, Standards or Safeguards: A Survey of the Delegation Doctrine in the States, 8 ADMIN. L.J. AM. U. 567 (1994). I am indebted to Creco's survey, but I have attempted to update and refine his summary of state doctrine. 
the Washington Supreme Court held that a statute authorizing the Director of the Department of Motor Vehicles to estabhish the maximum fees that can be charged to employment agencies was a constitutional delegation of legislative authority. ${ }^{109}$ The statute at issue used extremely broad language to authorize the Director to issue "reasonable rules and regulations," but did not contain specific standards to assist the Director in setting maximum fees. ${ }^{110}$ In upholding the statute, the court, citing Davis' treatise, reasoned that delegation promotes efficiency and flexibility, and avoids courts' need to rely on "vague adjectives of generality such as 'reasonable' or 'appropriate."111 While previous Washington law required some consideration of the degree of standards present in the statute, the court departed from this case law, suggesting that it be "relegated to a minor position in the juristic firmament."112 At the same time, the court noted, "[t]he focus of judicial inquiries . . . should shift from statutory standards to administrative safeguards and administrative standards."113 The court reasoned that such safeguards "can ensure that administratively promulgated rules and standards are as subject to public scrutiny and judicial review. ..."114

For purposes of analysis, I will classify states such as Washington as the "weak" nondelegation states.115 In addition to Washington, these states ${ }^{116}$ include California (strict separation of powers clause "S"), ${ }^{117}$ Iowa (S), ${ }^{118}$ Maryland (S), ${ }^{119}$ Oregon (S), ${ }^{120}$ and Wiscon-

109. Barry \& Barry, Inc., v. Washington Dep't. of Motor Vehicles, 500 P.2d 540, 546 (Wash. 1972) (en banc).

110. See id. at 541-42.

111. Id. at 543.

112. Id. at 545.

113. Id. at 543-44 (quoting Davis).

114. Id. at 545.

115. I include among the weak nondelegation states Arkansas, whose Supreme Court has held that the determining factor in assessing the constitutionality of a delegation is whether the legislature has retained control of the agency. See Arkansas Motor Carriers Ass'n v. Pritcliett, 798 S.W.2d 918, 920 (Ark. 1990). If legislative control is the test, then virtually any delegation survives so long as the legislature retains the ability to grant or withdraw powers.

116. To clarify the relationship between constitutional text and nondelegation doctrine, state constitutions with a strict separation of powers clause are designated with a " $\mathrm{S}$," general clause states with a "G," and those states with no separation of powers clause with an "N."

117. See People v. Wright, 639 P.2d 267, 271 (Cal. 1982) (uplolding reasonable grant of power to agency where suitable safeguards are in place to guide the agency's discretion).

118. See Iron Workers Local No. 67 v. Hart, 191 N.W.2d 758, 772 (Iowa 1971) (noting that "the important consideration is not whetler the statute delegating the power expresses precise standards but whether the procedure estabhshed for the exercise of power furnishes adequato safeguards for those affected by the administrative action"). 
sin (no explicit separation of powers clause, "N"). ${ }^{121}$ Notably, despite the relaxed approach of these state courts towards interpreting separation of powers principles, all of these states' constitutions contain strict separation of powers clauses, save Washington's and Wisconsin's, which contain no explicit separation of powers clause.

While in the 1960s and 1970s Davis, as well as many later commentators, suggested that this approach was the "trend" in state constitutionalism, its status as a trend is more questionable today. Many state supreme courts invoke a strong or moderate version of the nondelegation doctrine, rather than the weak version endorsed by federal courts. This is true regardless of the texts of state constitutions, although for some state courts constitutional text is given some weight in addressing the issue. No recent state supreme court decisions explicitly adopt the procedural safeguards approach in lieu of traditional nondelegation doctrines, as Washington and many other states did in the 1960s and 1970s.

\section{2. "Strong" Nondelegation States}

The recent Texas Supreme Court case, Texas Boll Weevil Eradication Foundation, Inc. v. Lewellen ("Boll Weevil") provides an example of a strong nondelegation decision. ${ }^{122}$ A 1993 Texas statute authorized the Commissioner of Agriculture to certify a nonprofit organization, representing cotton growers, to create a private entity called the "Official Cotton Growers' Boll Weevil Eradication Foundation" ("Foundation"). ${ }^{123}$ The Foundation was authorized to propose geographic eradication zones and to conduct referenda in each zone to establish whether those cotton growers wished to establish an official boll weevil eradication zone. If an official zone was established, the Foundation proposed assessments for cotton growers to pay subject to

119. See Department of Transp. v. Armacost, 532 A.2d 1056, 1060 (Md. 1987) (observing that delegations by the legislature, especially in areas of public healtl and safety, are valid when the legislature provides sufficient safeguards to guide the agency).

120. See Warren v. Marion County, 353 P.2d 257 (Or. 1960) (citing Davis and concluding that the important consideration is whether the procedure established in making the delegation provides adequate safeguards to those affected by agency actions, not whether the statute mandates specific standards).

121. See Gilbert v. Medical Examining Bd., 349 N.W.2d 68, 77-78 (Wis. 1984) (finding that broad grants of autliority, such as a grant to Medical Examining Board to "define and enforce professional conduct and unethical practices," will be uplield where adequate procedural safeguards are in place).

122. Texas Boll Weevil Eradication Found., Inc. v. Lewellen, 952 S.W.2d 454 (Tex. 1997).

123. TEX. AGRIC. CODE ANN. §§ 74.101-.127 (West 1995) (amended 1995 and 1997) (statutes governing foundations). 
the growers' approval in a subsequent referendum. ${ }^{124}$ The Foundation was also given broad powers to impose penalties for late payment of assessments and to recommend to the Department of Agriculture that nonpaying growers' crops be destroyed. ${ }^{125}$ The statute contained few checks on the Foundation's powers, apart from referenda and a requirement that the Commissioner of Agriculture certify the organization petitioning to become the Foundation. ${ }^{126}$

The court invalidated the statute on the grounds that the Texas Legislature had unconstitutionally delegated power to the Foundation in violation of the separation of powers clause of the Texas Constitution. ${ }^{127}$ After summarizing dissenting and concurring U.S. Supreme Court opinions and scholarly criticism endorsing a revival of the nondelegation doctrine, ${ }^{128}$ the court observed that "[s]tate courts may have less need to reinvigorate the doctrine, since they have historically been more comfortable with striking down state laws on this basis than their federal counterparts." 129

Illustrating the difference in approach between states like Texas and the federal courts, the court referred to three Texas cases addressing the nondelegation doctrine: in Texas Antiquities Committee v. Dallas County Community College District, ${ }^{130}$ a plurality of the justices expressed the view that the Antiquities Committee's charge to prevent demolition of all "buildings ... and locations of historical ... interest" was so vague that it failed to provide reasonable standards to support the delegation; ${ }^{131}$ Bullock v. Calvert struck down legisla. tion granting the Secretary of State the power to decide whether state funds could be used in primary elections because it gave the agency unbridled discretion; ${ }^{132}$ and Ex parte Leslie, ${ }^{133}$ in which the Texas Court of Criminal Appeals struck down a statute that gave the Live Stock Sanitary Commission the power to punish cattle farmers for failing to dip their cattle, because the statute did not contain reasonable standards to guide the Commission. While Boll Weevil addresses

124. See Boll Weevil, 952 S.W.2d at 457.

125. See id. at 457-58.

126. See id.

127. TEX. CONST. art. $2, \S 1$ (providing for division of powers of Texas State Government).

128. See Boll Weevil, 952 S.W.2d at $465-68$.

129. Id. at 468 .

130. Texas Antiquities Comm. v. Dallas County Community College Dist., 554 S.W.2d 924

(Tex. 1977).

131. Id. at 927.

132. Bullock v. Calvert, 480 S.W.2d 367 (Tex. 1972).

133. Ex parte Leslie, 223 S.W. 227 (Tex. Crim. App. 1920). 
legislative delegation to a private board, not an administrative agency, the case illustrates how the Texas Supreme Court adopts a much more rigorous test than federal courts for evaluating whether a legislative delegation of power is constitutional. ${ }^{134}$

Florida also endorses a strong separation of powers doctrine. The key modern case, Askew $v$. Cross Key Waterways, ${ }^{135}$ held unconstitutional an environmental statute delegating to an agency, the Administration Commission, the authority to designate geographic areas of critical state concern-subject to additional planning requirements-and, in certain instances, to adopt land use regnlations. The statute enunciated several limitations on agency designation of areas, allowing the "critical state concern" designation only if: (1) the area contains or has a significant impact upon "environmental, historical, natural, or archeological resources of regional or statewide importance"; (2) the area is "significant[ly] affected by, or [has] a significant effect upon, an existing or proposed major public facility or other area of major public investment"; or (3) the area has major development potential, such as the proposed site of a new community. ${ }^{136}$

Despite these limits on agency discretion in tlie statute, the Florida Supreme Court struck the statute as unconstitutional on nondelegation grounds. While the court acknowledged a need for an agency to "flesh out" policy, it also noted that this is "far different from that agency making the initial determination of what policy should be."137 Based on a somewhat formalistic interpretation of Florida's strict separation of powers clause, the court rejected Davis' procedural safeguards approach, holding that the Florida Legislature is required, at a minimum, to provide some standards or gnidelines to aid the agency in exercising its discretion. ${ }^{138}$ The court also acknowledged how the presence of such standards or guidelines aids judicial review. ${ }^{139}$ Since Askew, the Florida Supreme Court has had several occasions to revisit the doctrine and has consistently reaffirmed the need for specific standards and guidelines in legislation to validate a delegation of legislative authority to an agency. ${ }^{140}$

134. The contrast is obvious when the Boll Weevil case is compared to the Third Circuit's decision upholding a similar private delegation to increase beef sales in United States $v$. Frame, 885 F.2d 1119, 1127-29 (3d Cir. 1989).

135. Askew v. Cross Key Waterways, 372 So.2d 913 (Fla. 1979).

136. Id. at 914 (describing FLA. STAT. ANN. $\$ 380.05(2)$ (West 1975) (amended 1997 and 1998) (defining areas which may be designated areas of critical concern)).

137. Id. at 920 .

138. See id. at 924 .

139. See id. at 925 .

140. See, e.g., B.H. v. State, 645 So.2d 987, 993-94 (Fla. 1994) (juvenile escape statute invalid because it did not contain specific criteria or standards for agency to apply); Chiles v. 
States following a "strong" nondelegation approach, in a fashion similar to Texas (S) and Florida (S), include Arizona (S), ${ }^{141}$ Mllinois (S), ${ }^{142}$ Kentucky (S), ${ }^{143}$ Massachusetts (S), ${ }^{144}$ Montana (S), ${ }^{145}$ Nebraska (S), ${ }^{146}$ Nevada (S), ${ }^{147}$ New Hampshire (general separation of constitutional powers clause " $G$ "), ${ }^{148}$ New Mexico (S), ${ }^{149}$ New York (N), ${ }^{150}$ Ohio

Children, 589 So.2d 260, 266-67 (Fla. 1991) (statute authorizing an agency to take steps to reduce the state budget violates separation of powers doctrine because of "inadequate legislative direction"). But see Florida Gas Transmission Co. v. Public Serv. Comm'n, 635 So.2d 941, 944 (Fla. 1994) (pipeline certification statute contained sufficient standards and guidelines and thus did not violate nondelegation doctrine).

141. See State v. Williams, 583 P.2d 251, 254 (Ariz. 1978) (en banc) (standards necessary for valid delegation, although they need not be set forth in express terms if standards "might reasonably be inferred from the statutory scheme as a whole") (citing State v. Arizona Mines Supply Co., 484 P.2d 619, 625 (Ariz. 1971)).

142. See Stofer v. Motor Vehicle Cas. Co., 369 N.E.2d 875, 879 (111. 1977) (requiring statute to set forth persons and activities potentially subject to regulation, the harm to be prevented, and the general means available to the agency to prevent the identified harm); see also Thygesen v. Callahan, 385 N.E.2d 699, 701-02 (III. 1979) (striking statute based on Stofer test). At the same time, older cases and recent cases in Ilinois apply an "intelligible principle" test tliat is similar to many of the strong nondelegation states. See Hill v. Relyea, 216 N.E.2d 795, 797 (IIl. 1966) ("intelligible" principle required, although "the precision of the permissible standard must necessarily vary according to the nature of the ultimate objective and the problems involved"); see also Warrior v. Thompson, 449 N.E.2d 53, 57 (IIl. 1983) (applying "intelligible principle" test); People v. Carter, 454 N.E.2d 189, 190-91 (11. 1982) (applying Hill "intelligible principle" test). Because of the Hill test, Illinois probably belongs in the strong delegation category. See George Bunn et al., No Regulation Without Representation: Would Judicial Enforcement of a Stricter Nondelegation Doctrine Limit Administrative Lawmahing?, 1983 WIS. L. REV. 341, 34551 (arguing Mlinois lias one of the strongest nondelegation doctrines of any state).

143. See Legislative Research Comm'n v. Brown, 664 S.W.2d 907, 915 (Ky. 1984) (holding that a valid delegation of powers must contain sufficient standards to control the exercise of discretion, and that implicit in this standards requirement is the need for procedural safeguards) (citing Holsclaw v. Stepliens, 507 S.W.2d 462, 471 (Ky. 1974)).

144. See Opinion of the Justices to the House of Representatives, 471 N.E.2d 1266, 1273-74 (Mass. 1984) (upholding delegation to the Commissioner of Revenue to modify infrastructure development assessment rates, but noting that statute provided sufficient and "clear legislative standards" to guide the agency in making decisions).

145. See Bacus v. Lake County, 354 P.2d 1056, 1061 (Mont. 1960) (holding that the legislature must delimit powers delegated to an agency with "reasonable clarity" and provisions must be "sufficiently clear, definite, and certain to enable the agency to know its rights and obhiga. tions").

146. See Kwik Sliop, Inc. v. City of Lincohl, 498 N.W.2d 102, 108-09 (Neb. 1993) (striking down statute on grounds that legislature did not provide the local governing bodies "adequate, sufficient, and definite standards within which they are to exercise tlreir discretion"). But see Bosselman, Inc. v. State, 432 N.W.2d 226, 230-31 (Neb. 1988) (holding statute constitutional where legislature gave "reasonable himitations and standards for carrying out the delegated duties") (quoting Ewing v. Board of Equalization, 420 N.W.2d 685, 690 (Neb. 1988)).

147. See Slieriff, Clark County v. Luqman, 697 P.2d 107, 110-11 (Nev. 1985) (upholding controlled substances statute because statute provided sufficient standards to guide the agency for the purpose and power authorized).

148. See Guillou v. Division of Motor Velicles, 503 A.2d 838, 840-42 (N.H. 1986) (holding unconstitutional statute that authorized the Director of Motor Velicles to suspend or revoke a 
(N), ${ }^{151}$ Oklahoma (S), ${ }^{152}$ Pennsylvania (N), ${ }^{153}$ South Dakota (G), ${ }^{154}$ South Carolina (S), ${ }^{155}$ Virginia (S), ${ }^{156}$ and West Virginia (S). ${ }^{157}$ One state, Utah, has held that the legislature is prohibited from delegating any of its functions to specific persons within the executive department. ${ }^{158}$ In these states, statutes are periodically struck on nondelegation grounds. These state courts differ both in doctrine and in enforcement from their federal counterparts in assessing the nondelegation issue.

driver's license "for any cause which he may deem sufficient" because the statute failed to identify a "general" policy or to articulate "specific standards" for agency action).

149. See Montoya v. O'Toole, 610 P.2d 190, 191-92 (N.M. 1980) (requiring sufficient and clear legislative standards).

150. See Boreah v. Axelrod, 517 N.E.2d 1350, 1353-56 (N.Y. 1987) (striking a statute authorizing the Public Health Commission to "deal with any matters affecting the ... public health" because delegation did not contain reasonable safeguards and standards) (citing Levine v. Whalen, 349 N.E.2d 820,822 (N.Y. 1976)).

151. See Blue Cross v. Ratchford, 416 N.E.2d 614, 618 (Ohio 1980) (concluding that a rate statute is not an unconstitutional delegation if it establishes a "practical" standard or an "intelhgible principle" for an administrator to conform to and it contains procedures for review of agency discretion; where deference to agency expertise is important, court noted that it may be appropriate for agency itself to establisl standards).

152. See Ohver v. Oklahoma Alcolıolic Beverage Control Bd., 359 P.2d 183, 187 (Okla. 1961) (holding that for delegation to be vahd, the legislature must both declare the "policy of tlie law" and a "rule of action or framework" to guide the agency's exercise of power); Democratic Party v. Estep, 652 P.2d 271, 277-78 (Okla. 1982) (holding legislature must "establish its policies and set out definite standards for the exercise of an agency's rulemaking power" for delegation of power to be valid).

153. Altlough Pennsylvania has not articulated a single nondelegation doctrine, a concurring opinion provides one of the clearer statements. See Commonwealth v. Sessoms, 532 A.2d 775, 784 (Pa. 1987) (Papadakos, J., concurring) (arguing that legislation must contain adequate safeguards to guide and restrain the agency's exercise of delegated power, setting limits on agency powers and procedures).

154. See In re Application No. 5189-3, 467 N.W.2d 907, 913 (S.D. 1991) (noting that valid delegation must set fortli general policy and give tlie agency guidance).

155. See Bauer v. South Carolina State Hous. Autli., 246 S.E.2d 869, 876 (S.C. 1978) (finding statute unconstitutional if it grants "[a]bsolute, unregulated, and undefined discretion in an administrative body," although court may reasonably imply standards from legislation if not in express terms of statute).

156. See Cliapel v. Commonwealtlı, 89 S.E.2d 337, 342-43 (Va. 1955) (striking down statute that gave Dry Cleaner's Board authority to "promulgate such rules and regulations as it deemed necessary" to regulate the business because legislature failed to fix a standard to direct and guide the Board in rulemaking or to make findings tliat regulation required control by agency with broad discretionary powers).

157. See State ex rel. Barker v. Manchin, 279 S.E.2d 622, 631 (W. Va. 1981) (noting that legislature may not vest "uncontrolled discretion" in an agency, but must provide "sufficient standards or policy for guidance").

158. See State v. Gallion, 572 P.2d 683, 686-87 (Utah 1977). 


\section{3. "Moderate" Nondelegation Doctrine}

Many states do not clearly fit either the strong or weak approach to the nondelegation doctrine. In other words, these states do not always require specific standards, but may vary the degree of standards necessary depending on the subject matter of the statute or the scope of the statutory directive. At the same time, in these states procedural safeguards alone are rarely enough for a delegation to be valid.

For example, the Colorado Supreme Court has observed that, while the legislature must provide sufficient standards in a statute delegating power to an administrative agency, "this court has repeatedly emphasized the impracticality and inappropriateness, in many contexts, of requiring anything more than the most broad and general standards. . . ."159 The court stated that the test "is not simply whether the delegation is guided by standards, but whether there are sufficient statutory standards and safeguards, and administrative standards and safeguards, in combination, to protect against unnecessary and uncontrolled exercise of discretionary power."160 If adequate statutory standards and safeguards are not present, the court suggested that "it must be determined whether additional administrative standards and safeguards accomplish the necessary protection from arbitrary action." 161

States adopting an approach similar to Colorado (S) include: Alabama (S), ${ }^{162}$ Alaska (N), ${ }^{163}$ Connecticut (G), ${ }^{164}$ Delaware (N), ${ }^{165}$

159. Cottrell v. City of Denver, 636 P.2d 703, 708 (Colo. 1981) (en banc).

160. Id. at 709 .

161. Id. at 710. See also People v. Holmes, 959 P.2d 406, 410-11 (Colo. 1998) (applying Cottrell to uphold constitutionality of a statute establishing criminal penalties for violation of contraband regulations adopted by administrative leads of detention facilities).

162. See Bailey v. Shelby County, 507 So.2d 438, 443 (Ala. 1987) (upholding delegation but suggesting that botll standards and safeguards are relevant to assessing constitutionality of delegation).

163. See Usibelli Coal Mine, Inc. v. Department of Natural Resources, 921 P.2d 1134, 1145 (Alaska 1996) (noting that there is less need for standards where legislature has delegated "broad authority to an agency with expertise to regulate a narrowly defined field," but also acknowledging that statute contained both standards and safeguards); Municipality of Anchorage v. Anchorage Police Dep't. Employees Ass'n, 839 P.2d 1080, 1084-85 (Alaska 1992) (acknowledging relevance of imphicit or explicit standards, but noting that procedural safeguards are more important); see also Boehl v. Sabre Jet Room, Inc., 349 P.2d 585, 589-90 (Alaska 1960) (focusing on standards rather than safeguards).

164. See State v. Campbell, 617 A.2d 889, 895 (Conn. 1992) (stating standards must be "as definit[e] as is reasonably practicable under the circumstances") (citation omitted).

165. See Atlantis I Condominium Ass'n v. Bryson, 403 A.2d 711, 713 (Del. 1979) (looking to tetality of protections against administrative arbitrariness, including both standards and 
Georgia (S), ${ }^{166}$ Hawaii (N), ${ }^{167}$ Idaho (S), ${ }^{168}$ Indiana (S), ${ }^{169}$ Kansas (N), ${ }^{170}$ Louisiana (S), ${ }^{171}$ Maine (S), ${ }^{172}$ Michigan (S), ${ }^{173}$ Minnesota (S), ${ }^{174}$ Mississippi (G), ${ }^{175}$ Missouri (S), ${ }^{176}$ New Jersey (S), ${ }^{177}$ North Carolina (G), ${ }^{178}$

safeguards created by the legislature or the agency) (citing Meyer v. Lord, 586 P.2d 367, 371 (Or. Ct. App. 1978)).

166. See Department of Transp. v. City of Atlanta, 398 S.E.2d 567, 571-72 (Ga. 1990) (requiring sufficient standards, such as a "public interest" standard, to meet constitutional delegation).

167. See In re Kauai Elec. Div., 590 P.2d 524, 534-35 (Haw. 1978) (upholding "just and reasonable" rate standard as adequate standard to meet constitutional nondelegation test).

168. See State v. Kellogg, 568 P.2d 514, 517-18 (Idaho 1977) (upholding delegation to the Board of Pharmacy to regulate prescription drug dispensing "in the interest of public health and safety," but observing that there exists a point at which it is "unreasonable and impracticable" for the legislature to fix specific rules); see also Sun Valley Co. v. City of Sun Valley, 708 P.2d 147, 150-51 (Idaho 1985) (noting that standards are not necessary where legislature has not delegated legislative authority to the executive, but that normally both standards and safeguards are necessary).

169. See Meier v. American Maize-Products Co., 645 N.E.2d 662, 671 (Ind. Ct. App. 1995) (holding standards necessary, but precision will vary with context); Steup v. Indiana Hous. Fin. Auth., 402 N.E.2d 1215, 1228 (Ind. 1980) (observing that legislature may set terms very broadly, but adding "[s]uch terms get precision from the knowledge and experience of [persons] whose duty it is to administer the statutes, and then such statutes become reasonably certain guides in carrying out the will and intent of the Legislature").

170. See State ex rel. Tomasic v. Unified Gov't, 955 P.2d 1136, 1148 (Kan. 1998) (noting legislature can delegate administrative power but not legislative power, and that such delegation must contain "sufficient policies and standards to guide the nonlegislative body in exercising the delegated power"); Vakas v. Kansas Bd. of Heahing Arts, 808 P.2d 1355, 1361 (Kan. 1991) (holding legislature is only required to set forth standard in general terms, although courts should also look te entirety of statute and procedural safeguards).

171. See State v. All Pro Paint \& Body Shop, Inc., 639 So.2d 707, 716-17 (La. 1994) (noting that "regard must be given to the purpose and scope of the act, the subject matters covered therein, the duties prescribed, and the broad or narrow powers granted," but that "the standards which must accompany delegations must not be unlimited, unreasonable, or permit arbitrary action by the administrative body"); State v. Broom, 439 So.2d 357, 362 (La. 1983) (guiding statutory standards are relevant, but should be de-emphasized in favor of procedural safeguards).

172. See Stato v. Boynton, 379 A.2d 994, 995 (Me. 1977) (finding precise standards necessary, but where not practicable, procedural safeguards may substantially compensate for lack of standards).

173. See People v. Turmon, 340 N.W.2d 620, 623 (Mich. 1983) (requiring statutory standard to be "as reasonably precise as the subject matter requires or permits," although the precision of the standard "will vary with the complexity and/or the degree to which subject regulated will require constantly changing regulation") (citations omitted).

174. See Minnesota Energy \& Econ. Dev. Auth. v. Printy, 351 N.W.2d 319, 350-51 (Minn. 1984) (requiring administrative standards or statutory standards to limit discretion).

175. See State ex rel. Patterson v. Land, 95 So.2d 764, 777 (Miss. 1957) (holding that a statute must "reasonably define" the area in which the agency operates and limitations upon its power).

176. See Menorah Med. Ctr. v. Health \& Educ. Facility Auth., 584 S.W.2d 73, 83-84 (Mo. 1979) (en banc) (noting general rule that standards are required to guide agency discretion, but exceptions apply where it is impracticable, where delegation relates to protection of public morals, health, safety, and general welfare, or where personal fitness is a factor for agency consideration). 
North Dakota (N), ${ }^{179}$ Rhode Island (G), ${ }^{180}$ Tennessee (S), ${ }^{181}$ Vermont (S), ${ }^{182}$ and Wyoming (S). ${ }^{183}$ While none of these states allow delegation with procedural safeguards alone, at a minimum, general legislative statements of policy or legislative statements of pohicy with procedural safeguards are required for a valid delegation. I will refer to them as the "moderate" nondelegation states for purposes of analysis. Arguably, some of these moderate states take a similar approach in doctrine to federal courts. Despite the doctrinal similarities, though, these state courts are much more likely to strike down statutes as unconstitutional than their federal counterparts. Thus, although there may be doctrinal similarities, there are differences in the enforcement levels between the federal system and moderate nondelegation states.

177. See Township of Mount Laurel v. Department of the Pub. Advocate, 416 A.2d 886, 891 92 (N.J. 1980) (allowing standards accompanying delegation to be "quite general" or even implied, and upholding delegation to agency to determine what was in the public interest because of existing court decisions defining "public interest").

178. See Town of Spruce Pine v. Avery County, 488 S.E.2d 144, 146-47 (N.C. 1997) (observing that botlu standards and safeguards are present); Adams v. Nortlu Carolina Dep't of Natural Resources, 249 S.E.2d 402, 410-11 (N.C. 1978) (noting that in searching for an "adequate guiding standard" court can consider whether there are procedural safeguards).

179. See Trinity Med. Ctr. v. North Dakota Bd. of Nursing, 399 N.W.2d 835, 841-46 (N.D. 1987) (requiring statute to set forth reasonably clear guidelines within which agency fact finding power is to be exercised).

180. See Marran v. Baird, 635 A.2d 1174, 1179 (R.I. 1994) (noting that a delegation is constitutional "[a]s long as the Legislature that creates the agency demonstrates standards or principles to confine and guide the agency's power"); Bourque v. Dettore, 589 A.2d 815, 818 (R.I. 1991) (noting that constitutionality of delegation depends upon "the specificity of the functions delegated, the standards accompanying the delegation, and the safeguards against administrative abuse" and that either standards or procedures to confine and guide the agency's discretion can suffice).

181. See West v. Tennessee Hous. Dev. Agency, 512 S.W.2d 275, 281 (Tenn. 1974) (explaining that where highly detailed determinations need to be made by agency, greater leeway in delegation allowed).

182. See Rogers v. Watson, 594 A.2d 409, 414 (Vt. 1991) (requiring statute to contain "basic standard" to guide the agency).

183. See In re Bessemer Mt., 856 P.2d 450, 454 (Wyo. 1993) (holding when legislature delegated power to an agency with only very broad standards, the agency must "invoke expertise to create standards, which will furnish notice to the public of how the decision may be reached"). 
Table 1

State Judicial Approaches to the Nondelegation Doctrine

\begin{tabular}{|c|c|c|}
\hline $\begin{array}{l}\text { Weak (Davis- } \\
\text { procedural safe- } \\
\text { guard alone) }\end{array}$ & $\begin{array}{l}\text { Moderate (legislative } \\
\text { statement of policy) }\end{array}$ & $\begin{array}{l}\text { Strong (specific standards in } \\
\text { legislation) }\end{array}$ \\
\hline $\begin{array}{l}\text { Arkansas (S) } \\
\text { California (S) } \\
\text { Iowa (S) } \\
\text { Maryland (S) } \\
\text { Oregon (S) } \\
\text { Washington (N) } \\
\text { Wisconsin(N) }\end{array}$ & $\begin{array}{l}\text { Alabama (S) } \\
\text { Alaska (N) } \\
\text { Colorado (S) } \\
\text { Connecticut(G) } \\
\text { Delaware (N) } \\
\text { Georgia (S) } \\
\text { Hawaii (N) } \\
\text { Idaho (S) } \\
\text { Indiana (S) } \\
\text { Kansas (N) } \\
\text { Louisiana (S) } \\
\text { Maine (S) } \\
\text { Michigan (S) } \\
\text { Minnesota (S) } \\
\text { Mississippi (G) } \\
\text { Missouri (S) } \\
\text { New Jersey (S) } \\
\text { Nortli Carolina (G) } \\
\text { North Dakota (N) } \\
\text { Rliode Island (G) } \\
\text { Tennessee (S) } \\
\text { Vermont (S) } \\
\text { Wyoming (S) }\end{array}$ & $\begin{array}{l}\text { Arizona (S) } \\
\text { Florida (S) } \\
\text { Illinois (S) } \\
\text { Kentucky (S) } \\
\text { Massachusetts (S) } \\
\text { Montana (S) } \\
\text { Nebraska (S) } \\
\text { Nevada (S) } \\
\text { New Hampshire (G) } \\
\text { New Mexico (S) } \\
\text { New York (N) } \\
\text { Ohio (N) } \\
\text { Oklahoma (S) } \\
\text { Pennsylvania (N) } \\
\text { Soutlı Dakota (G) } \\
\text { South Carolina (S) } \\
\text { Texas (S) } \\
\text { Utah (S) } \\
\text { Virginia (S) } \\
\text { West Virginia (S) }\end{array}$ \\
\hline
\end{tabular}

\section{Rules Review and Separation of Powers in the States}

While the nondelegation doctrine places himits on legislative delegation of authority to agencies, Chadha restricts the U.S. Congress's review of otherwise valid delegations. Legislative review of rulemaking and other agency action takes on many forms in the states, and is often built into state Administrative Procedure Acts ("APAs") or separate statutes defining a legislative rules review process. Although some states provide for a one or two chamber veto, similar to that at issue in Chadha, in many states, legislative review of rules takes on a slightly different form. Often, a rules review committee within the legislature has the power to veto, suspend, or delay rules or the power to allow proposed rules to lapse absent approval, making legislative committee approval of rules a mandatory require- 
ment in the rulemaking process. ${ }^{184}$ In some states, like Florida, a joint committee is assigned responsibility to review all agency rules, but its role is almost entirely advisory. ${ }^{185}$

As Arthur Bonfield notes, "in the absence of a constitutional provision expressly authorizing such action, nonstatutory legislative vetoes or suspensions of particular agency rules are probably impermissible under most state constitutions."186 As a matter of state constitutional doctrine, Bonfield accurately describes the predominant approach of state courts in approaching the doctrine. With few exceptions, state court opinions addressing the constitutionality of legislative veto and mandatory legislative committee approval of rules endorse the formahism of the Chadha court and hold the practice unconstitutional. Although a few states have special constitutional authorization for the legislative veto ${ }^{187}$ or joint resolution ${ }^{188}$ oversight of agency rulemaking, the full one or two house legislative veto, as in

184. For a description of various states' approaches, see L. Harold Levinson, Legislative and Executive Veto of Rules of Administrative Agencies: Models and Alternatives, 24 WM. \& MARY L. REV. 79 (1982); NAARR, supra note 98.

185. Florida's Joint Administrative Procedures Committee ("JAPC") reviews all proposed rules for purposes of determining whether the rule comports with prescribed standards, including whether the rule is "necessary to accomplish the apparent or expressed objectives of the specific provision of law which the rule implements." FLA. STAT. ANN. § 120.545(1) (West 1996) (amended 1996). JAPC can object to rules, but its objection is not binding on the agency. An agency may refuse to comply with JAPC's recommendations. However, agency failure to respond at all to a JAPC objection within a period of 30 or 45 days, depending on whether the agency is a collegial body, constitutes withdrawal of the rule. See id. $\S 120.545(6)$.

186. ARTHUR EARL BONFIELD, STATE ADMINISTRATIVE RULE MAKING $\S 8.3 .2$, at 498 (1986).

187. Iowa's Constitution contains a provision that expressly authorizes its General Assembly to overcome an agency rule by joint resolution. See IOWA CONST. art. III, § 40; see also Iowa Fed'n of Labor v. Department of Job Serv., 427 N.W.2d 443, 445.48 (Iowa 1988) (reconciling Iowa's constitutional provision with the power of courts to interpret and declare laws invahd). Connecticut's Constitution provides that administrative regulations of the executive department may be disapproved by the general assembly or a committee thereof in such a manner as shall by law be prescribed. See CONN. CONST. art. 2. See also CONN. GEN. STAT. ANN. \$§ 4-170, 4-171 (West 1998). Nevada's Constitution, amended in 1996, also authorizes a legislative committee to suspend agency regulations. See NEv. CONST. art. $3, \S 1$.

188. South Carolina's Constitution, article III, section 18, allows joint resolutions to have the force and effect of laws. A state Attorney General opinion held the veto process constitutional, on the grounds that article III, section 18, of South Carolina's Constitution provides that joint resolutions liave the force of law. See 1986 S.C. Op. Att'y Gen. 238. Before this amend. ment was added to South Carolina's Constitution, joint resolution veto had been found unconstitutional. See Reith v. South Carohna State Hous. Auth. (S.C. Ct. App.), rev'd on other grounds, 225 S.E.2d 847 (S.C. 1976) (holding concurrent resolution approval of rules unconstitutional because it interferes with the executive's obhigation to enforce the law, but the appellate court held the offending clause non-severable and declared the entire statute unenforceable). In 1996, Nevada amended its constitution to allow nullification of agency regulations by majority vote of its legislative body. See NEv. CoNST. art. 3, § 1. In 1992, New Jersey amended its constitution, authorizing legislative invalidation of rules by concurrent resolution. See N.J. CoNST. art. 5, $\S 4,16$ (1999). 
Chadha, has been held unconstitutional in every state to consider this issue, with the singular exception of Idaho. ${ }^{189}$

A similar, perhaps more prevalent, form of rules review is the "mandatory approval" rules review committee-a committee comprised of legislators or individuals appointed by the legislature that has true authority to veto rules without going through either or both chambers. Such review has been held unconstitutional in almost every state considering the issue. Courts in New Hampshire, Oregon, Kentucky, and West Virginia have found the practice to be unconstitutional. ${ }^{190}$ A couple of states, such as Michigan ${ }^{191}$ and South Dakota ${ }^{192}$ have express constitutional provisions that authorize suspension of agency rules by a designated legislative committee, but only on a temporary basis when the legislature is not in session. Wisconsin stands alone in concluding the practice is constitutional, although its

189. Of states addressing the constitutionality of the legislative veto, courts in Alaska, Kansas, New Jersey, Pennsylvania, and West Virginia have found the veto unconstitutional. See State v. A.L.I.V.E. Voluntary, 606 P.2d 769, 777-78 (Alaska 1980) (rejecting the argument that the legislature could condition its delegation of rulemaking authority to agencies by reserving a veto itself, holding that this violated the separation of powers provision in Alaska's constitution); State ex rel. Stephen v. Kansas House of Representatives, 687 P.2d 622, 637-38 (Kan. 1984) (holding that concurrent resolution legislative veto violates separation of powers and presentment requirements in Kansas' Constitution); General Assembly v. Byrne, 448 A.2d 438, 439 (N.J. 1982) (holding joint resolution veto unconstitutional on separation of powers grounds because it "excessively interfere[d] with the functions of the executive branch ... by impeding the Executive in its constitutional mandate to faithfully execute the law ... [and] by allowing the Legislature te effectively amend or repeal existing laws without participation by the Governor"); Commonwealth v. Sessoms, 532 A.2d 775, 780-81 (Pa. 1987) (holding concurrent resolution veto unconstitutional as apphed to administrative rulemaking, which is essentially executive in nature); State ex rel. Barker v. Manchin, 279 S.E.2d 622, 632-36 (W. Va. 1981) (observing that legislative review process, which made available full legislature's review of rules, abrogated the veto power of the governor and usurped the traditional executive role).

190. The committee veto has been addressed in several cases, including: Legislative Research Comm'n v. Brown, 664 S.W.2d 907, 920 (Ky. 1984) (holding unconstitutional, on bicameralism and presentment grounds, statutes that give the Legislative Researcl Commission the power to approve rules in advance of final adoption and to suspend them for periods in between legislative sessions); Missouri, discussed infra; Michigan, discussed infra; Opinion of the Justices, 431 A.2d 783, 788 (N.H. 1981) (advisory opinion) (declaring unconstitutional proposed legislation that would require agency rules to be submitted to a standing committee in each house of the legislature, on the grounds that the legislature cannot delegate lawmaking authority to a smaller body); Gilliam County v. Department of Envtl. Quality, 849 P.2d 500, 505 (Ore. 1993) (en banc) (holding unconstitutional legislative committee power to veto rules); Manchin, 279 S.E.2d at 636 (invahdating mandatory review of rules, subject to veto, by the Legislative Rule-Making Review Committee, a body composed of twelve legislators); State ex rel. Meadows v. Hechler, 462 S.E.2d 586, 594 (W. Va. 1995) (holding unconstitutional similar committee suspension process).

191. See Mich. CONST. art. IV, $\S 37$ (providing for joint committee suspension of rnles on a temporary basis); see also MrCH. COMP. LAWS ANN. $\S 24.235$ (amended 1995), 24.236 (West 1994).

192. See S.D. CONST. art. III, $\S 30$ (providing for joint committee suspension of rules on a temporary basis). 
legislative review process provides for temporary committee suspension only. ${ }^{193}$

Cases decided recently in Missouri and Michigan illustrate how the approach of Chadha is alive and well in some states as a restriction on legislative oversight of agency rulemaking. In both contexts, the state court, like the U.S. Supreme Court in Chadha, followed a formalistic textual interpretation of the applicable state constitution. Yet neither opinion discusses the policy merits or faults of the legislative veto, or the institutional differences affecting federal and state legislative oversight of agency rulemaking.

The Missouri Supreme Court recently struck down a suspension of agency proposed rules by the state's Joint Committee on Administrative Rules (JCAR), whicl was formed in 1975. ${ }^{194} \mathrm{JCAR}$, whose veto mechanism had been the subject of scholarly criticism, ${ }^{195}$ is composed of five senators appointed by the president pro tem of the Senate and five representatives appointed by the speaker of the House. ${ }^{196}$ Initially JCAR reviewed rules and reported findings and recommendations to the General Assembly, the Commissioner of Administration, and the elected state officer who promulgated the rule. Subsequent legislation authorized JCAR to suspend rules, ${ }^{197}$ granted the right to prior approval of rules, ${ }^{198}$ and established the power to nullify rules already in effect. ${ }^{199}$

The 1997 challenge to JCAR's authority involved rules proposed by Department of Natural Resources ("DNR") in implementing

193. See infra notes $238-44$ and accompanying text. Pennsylvania has refused to hold unconstitutional its committee review process, which allows an objecting committee to bar publication of final regulations. See generally Department of Envtl. Resources v. Jubelirer, 614 A.2d 204 (Pa. 1992).

194. See Missouri Coalition for the Env't v. Joint Comm. on Admin. Rules, 948 S.W.2d 125, 128 (Mo. 1997) (en banc). Following this case, the Missouri Legislature amended its legislative review process to comply with its constitution. See MO. ANN. STAT. § 536.028 (West Supp. 1999).

195. See Kenneth D. Dean, Legislative Veto of Administrative Rules in Missouri: A Constitutional Virus, 57 Mo. L. REv. 1157, 1216 (1992) (concluding that Missouri's legislative veto and suspension mechanisms "are especially likely to be declared unconstitutional because they involve powers exercised by a committee"); Scott Welman, Comment, Joint Committee on Administrative Rules: The Missouri Legislature's Disregard for the Missouri Constitution, 58 UMKC L. REV. 115, 126 (1989) (suggesting Missouri's legislative veto is unconstitutional).

196. See Mo. ANN. STAT. $\S 536.037$ (West 1988) (amended 1994) (creating the committee and outlining its membership).

197. See $\$ 173.612$ (amended 1991) (authorizing JCAR to suspend rules promulgated by the state department of education). See also Dean, supra note 195, at 1217-23.

198. See, e.g., $\S 197.445$ (amended 1993, 1995, 1997) (preventing the state department of health services from adopting a rule unless promulgated according to JCAR).

199. See, e.g., § 277.160 (amended 1993, 1995). See also Deau, supra note 195, at 1224-31. 
Missouri's Solid Waste Management Law ("MSWML"). Under the rules review process, the DNR was required to submit proposed rules to JCAR when it submitted its proposed rules to the secretary of state for notice and comment publication. ${ }^{200}$ JCAR could disapprove such a rule, ${ }^{201}$ but if it failed to suspend the rule within twenty days, the rule was deemed approved by JCAR and the agency was permitted to submit the rule for final publication. ${ }^{202}$ Certain rules, such as those promulgated under MSWML, could be suspended after pubhication at any time by JCAR. ${ }^{203}$

Despite Missouri case law acknowledging that complete separation of powers is not always required, ${ }^{204}$ the court reasoned that Missouri's statute authorizing JCAR to veto DNR's solid waste rules was unconstitutional because it interfered with executive branch powers and circumvented the Missouri Constitution's bill passage and presentment requirements. ${ }^{205}$ To begin, echoing the Chadha majority, the court reasoned, that Missouri's Constitution confines the power of its legislature to enacting laws and does not allow the legislature to execute laws already enacted. JCAR's veto of DNR's solid waste rules violated this provision to the extent it suspended promulgation of DNR rules pending JCAR review, prevented promulgation and enforcement of the rules JCAR disapproves, and permitted JCAR to suspend and withdraw rules already promulgated by DNR. Although the court noted that the legislature may attempt to control the executive branch either by passing amendments or other legislation subject to the governor's veto, by appropriation, by committee hearings, investigations, or information requests, JCAR's veto effectively worked as a "unilateral control," which is constitutionally prohibited. ${ }^{206}$ Also echoing Chadha, the court observed, the Missouri Constitution's passage and presentment requirements form a barrier to the constitu-

200. See § $260.225 .4,536.024$ (West Supp. 1999).

201. See id.

202. See $§ 260.225 .3$.

203. See $\$ 260.255 .4$.

204. See generally Rhodes v. Bell, 130 S.W. 465 (Mo. 1910); Albright v. Fisher, 64 S.W. 106 (Mo. 1901) (holding that a circuit court has no authority to entertain a suit to restrain a city municipal assembly from passing a right-of-way ordinance).

205. The Missouri Constitution contains a strict separation of powers clause, which states: The powers of government shall be divided into three distinct-departments the legislative, executive, and judicial-each of which shall be confided to a separate magistracy, and no person, or collection of persons, charged with the exercise of powers properly belonging to one of those departments shall exercise any power properly belonging to either of the others, except in the instances in this constitution expressly directed or permitted.

Mo. CoNST. art II, $\S 1$.

206. See Missouri Coalition, 948 S.W.2d at 133-34. 
tionality of JCAR's veto. ${ }^{207}$ Missouri's constitution provides, "[n]o law shall be passed [by the legislature] except by bill. . .."208 And every bill that passes Missouri's House of Representatives and Senate must be presented to and approved by the Governor prior to becoming law. ${ }^{209}$

Michigan reached a remarkably similar result, relying on its presentment clause as much as separation doctrines, when it addressed the constitutionality of joint legislative committee review and suspension of rules. In 1997, the Michigan Court of Appeals held that the sections of Michigan's APA, which give the legislature's Joint Committee on Administrative Rules ("JCAR") the authority to veto administrative rules, violates the enactment and presentment clauses of Michigan's Constitution, and thus runs afoul of separation of powers principles. ${ }^{210}$

JCAR is a committee comprised of five members of the House of Representatives and five members of the Senate. Sections 45 and 46 of Michigan's APA required agencies to submit a rule to JCAR for its approval and obtain a certificate of approval prior to transmission of rules to the Secretary of State for publication. ${ }^{211}$ Once JCAR disapproved a rule, Michigan's APA prohibited the agency from adopting the rule unless the legislature, by concurrent resolution, approved the rule or JCAR subsequently approved the rule. ${ }^{212}$

JCAR's approval process was held unconstitutional by the Michigan Court of Appeals. ${ }^{213}$ After referencing an Alaska case that held joint resolution annulment of rules unconstitutional and New Hampshire and West Virginia cases that held joint committee veto of rules unconstitutional, ${ }^{214}$ the court addressed whether Michigan's provision violated separation of power principles. ${ }^{215}$ Although Michigan's Constitution contains an exphicit strict separation of powers provision, the court reasoned that sections 45 and 46 of Michigan's APA were problematic primarily because they violated the enactment

207. See id. at 134-35.

208. Mo. CONST. art. III, $\S 21$.

209. See id. § 31 .

210. See Blank v. Department of Corrections, 564 N.W.2d 130, 132-33 (Mich. Ct. Apps. 1997 .

211. See Mich. COMP. LAWS ANN. $\S \S 24.245,24.246(1)$ (West 1994).

212. See id. $\S 24.245(9)(\mathrm{a})$-(b).

213. See Blank, 564 N.W.2d at 141.

214. State v. A.L.I.V.E. Voluntary, 606 P.2d 769 (Alaska 1980); Opinion of the Justices, 431 A.2d 783 (N.H. 1981); State ex rel. Barker v. Manchin, 279 S.E.2d 622 (W. Va. 1981)).

215. See id. at 137-38. 
and presentation requirements of Michigan's Constitution. ${ }^{216}$ The court found that the provisions violated enactment requirements because they did not require the legislature to undergo the requirements of the constitution prior to enacting a law. ${ }^{217}$ Michigan's Constitution provides that "[t]he legislative power of the State of Michigan is vested in a senate and a house of representatives"218 and that "[a]ll legislation shall be by bill and may originate in either house."219 Further, it requires the concurrence of a majority of the members of each house prior to becoming law. ${ }^{220}$ The provisions were found to violate presentation provisions to the extent that they bypassed the participation of Michigan's Governor in the lawmaking process. Under Michigan's Constitution, "[e]very bill passed by the legislature shall be presented to the governor before it becomes a law. ..."221 As the court observed, "[b]y giving JCAR the authority to veto administrative rules proposed by an executive agency, the Legislature has delegated legislative power to a smaller legislative body that can effectively negate a valid action of an agency without following the requirements [of the constitution]."222

Three things about the Michigan case are notable. First, the court reasoned that agency promulgation of rules is not a legislative function, but by implication is executive in nature. ${ }^{223}$ Although the outcome of the case probably would not have been different had the court deemed rulemaking a legislative function, this may work to save programs similar to Michigan's in other states. Second, the court observed that by violating the Michigan Constitution's enactment and presentment clauses, the JCAR approval process implicitly violated separation of powers. ${ }^{224}$ Even in states like Michigan, which has an exphicit strict separation of powers provision in its constitution, courts will look to other requirements the constitution imposes on the lawmaking process. Third, the court observed that, even without the JCAR veto, Michigan retained a "legislative disapproval process" allowing the legislature, by joint resolution, to send a message of

216. See id.

217. See id. at 135 .

218. MICH. CONST. art. IV, § 1 .

219. Id. § 22 .

220. See id. § 26.

221. Id. § 33 .

222. Blank, 564 N.W.2d at 136.

223. See id. (citing Westervelt v. Natural Resources Comm'n, 263 N.W.2d 564, 576-77 (Mich. 1978)).

224. See id. (citing INS v. Chadha, 462 U.S. 919, 946 (1983) (stating enactment and presentation clauses "are integral parts of the constitutional design for the separation of powers")). 
disapproval of rules to agencies. ${ }^{225}$ The court also observed that the power of the Michigan Legislature to act in between sessions was preserved by joint committee suspension, which Michigan had provided in its constitution. ${ }^{26}$ Thus, the legislature has some participation in agency rulemaking, and agencies are prohibited from passing rules when the legislature is not in session. ${ }^{227}$

Unfortunately, state courts adopting a result similar to Chadha, sucl as courts in Missouri and Michigan, provide little more than a formalistic rationale for it. The texts of state constitution separation of powers clauses are often invoked in the separation of powers debate. However, the case law suggests the approach of a state court in evaluating rules review is much less likely a result of the state constitution's separation of powers clause so much as it is dependent on a variety of other formal constitutional and judicial factors, including: 1) whether the state's constitution contains bicameralism, or other enactment requirements, 2) whether the state's constitution contains a presentment clause, allowing gubernatorial participation in lawmaking, 3) whether the state's constitution contains a "take care" clause, and 4) whether rulemaking is considered to be an executive or legislative function within the state. The courts may also consider whether a rule is regarded witl coequal status as a "law" within the state and how the state's executive branch is structured. With respect to each of these doctrinal factors, there is a convergence among the state approaclies, although differences among some states render in question the constitutional status of at least some state approaches to rules review.

As with the Supreme Court's Chadha opinion, functional and policy rationales are given short shrift by state courts addressing

225. See MICH. COMP. LAWS ANN. § 24.251 (West 1994).

226. The Michigan Constitution provides:

The legislature may by concurrent resolution empower a joint committee of the legislature, acting between sessions, to suspend any rule or regulation promulgated by an administrative agency subsequent to the adjournment of the last preceding regular legislative session. Such suspension shall continue no longer than the end of the next regular legislative session.

MICH. CONST. art.IV, $\S 37$. This provision was added to Michigan's Constitution in 1961 in response to a 1958 Attorney General opinion that administrative rules could not be suspended by the Legislature under Michigan's constitution without passing a bill that becomes law. See Blank, 564 N.W.2d at 137.

227. The Michigan Court of Appeals acknowledged this again in a recent case applying Blank. In Michigan State Employees Association v. Michigan Liquor Control Commission, 591 N.W.2d 353, 358 (Mich. Ct. App. 1998), the court observed that the Legislature retains authority to suspend rules by concurrent resolution in between legislative sessions. 
limits on legislative oversight. Such rationales, if addressed by the courts, would have given some normative basis for the decisions, as there are several pohicy rationales against legislative veto of agency rulemaking. For example, the political scientist Marcus Ethridge conducted a study of Michigan's rules review process and its impact on environmental policymaking in the late $1970 \mathrm{~s} .{ }^{228}$ His study chronicled some of the extreme problems posed by such a review process. During the period Ethridge studied, Michigan's committee spent most of its time evaluating complaints about regulatory policy raised by the public, not engaging in "traditional" oversight-i.e., monitoring policy for efficiency or evaluating whether pohicy contradicts legislative intent. It was noted that "the most obvious regularity in committee discussions is a general predisposition to support agency decisions that can be reasonably interpreted as a good faith compromise between opposing viewpoints."229 This led to notable frustration among agency administrators. Based on a study of regulatory aggressiveness and stringency from November 1977 to July 1980, Ethridge concluded that agencies with high degrees of access to regulated interests (such as licensing boards) were less likely to have rules disapproved. By contrast, rules review had a high impact on environmental policymaking, where regulated interests complained regularly, inviting JCAR to second-guess agency decisions on political grounds. ${ }^{230}$ This is part of the concern that separation of powers principles have evolved to guard against, although this functional rationale received hittle or no discussion by the Missouri or Michigan courts.

While there appears to be some doctrinal consensus among the states in addressing the issue of the legislative veto and mandatory committee approval of rules, not all states converge in their result. Courts in Idaho and Wisconsin have explicitly authorized stronger legislative oversight than other states. In Mead $v$. Arnell, a majority of the Idaho Supreme Court held tliat suspension of rules by concurrent resolution, in circumstances where the legislature believes the rules are inconsistent with the statute on which those rules are based, is constitutional. ${ }^{231}$ This is the only case that lias held that a twohouse legislative veto is vahd in the absence of an express constitutional provision authorizing the device. ${ }^{232}$

228. Marcus E. EThridge, Legislative Participation in IMPLementation: Policy THROUGH POLITICS 81-98 (1985).

229. Id. at 86.

230. See id. at 86-87.

231. Mead v. Arnell, 791 P.2d 410, 418-20 (Idaho 1990).

232. The New Hampshire Supreme Court, in an advisory opinion, has suggested that the legislative veto may survive constitutional muster. See Opinion of the Justices, 431 A.2d 783, 
While it is the best opinion advocates of strong legislative oversight probably have, the case is also difficult to follow and problematic. The court noted under Idaho's Constitution, only the legislature "has the power to make law," and that "a statute or law" may "be enacted only by a bill, passed by both houses of the legislature and signed by the governor, or rejected by the governor, [and] passed over the veto by the legislature."233 The opinion observed, however, that adoption or rescission of executive rules is not subject to this requirement because this applies only to statutory laws. Agency rules, although they may have the "force and effect of law" are not "equal in dignity or status to statutory law.".234 In addition, the court rejected the argnment that concurrent resolution veto usurps the executive function or interferes with the "constitutionally mandated duty [of the executive] to execute the laws of this state."235 Despite dicta declaring the veto constitutional, the court held the particular legislative veto at issue in the case unconstitutional because the legislature had failed to state explicitly, as the statute required, the grounds for issuing the veto.

The case is important because it illustrates how, in some states, concurrent resolution legislative veto may be constitutional. Although it addresses concurrent resolution and not the one-house veto, the opinion's reasoning echoes Justice White's dissent in INS $v$. Chadha. Justice White would have upheld the legislative veto as "the most effective if not the only means to insure [Congress's] role as the nation's lawmakers." ${ }^{236}$ Justice White found legislative delegation to executive branch agencies without retaining a veto over agency rules "risk[ing] unaccountable pohicymaking by those not elected to fill that role."237 Like Woodrow Wilson, Justice White thought that the increased legislative tendency to delegate to agencies demanded creative legislative responses, such as the veto, designed to ensure that the legislature continued to reign supreme in the lawmaking process.

A Wisconsin statute authorizing a legislative committee to suspend a rule temporarily, pending prompt action by both houses of

787 (N.H. 1981) (stating in dicta that the legislative veto may not be unconstitutional, because the legislature can condition its delegation of lawmaking authority on some form of legislative approval).

233. Mead, 791 P.2d at 414 .

234. Id. at 415 .

235. Id. at 417 .

236. INS v. Chadha, 462 U.S. 919,978 (1983) (White, J., dissenting).

237. Id. at 968 . 
the legislature and presentment to the governor for signing or veto, has also been held constitutional. The challenged process allowed Wisconsin's Joint Committee for Review of Administrative Rules ("JCRAR"), consisting of five senators and five representatives appointed by the legislative leadership, to temporarily suspend rules for very specific grounds. ${ }^{238}$ Within 30 days of suspension, Wisconsin's JCRAR was required to introduce into each house of the legislature a bill to repeal the suspended rule, for consideration at any regular session. ${ }^{239}$ Suspension, however, is very limited: "If both bills . . . are defeated, or fail to be enacted in any other manner [including by veto of the governor], the rule remains in effect and the committee may not suspend it again."240

The Wisconsin Supreme Court, without a single dissent, held this process constitutional, but it stressed the temporary and limited nature of the committee's action. ${ }^{241}$ The court noted that it interprets the separation of powers principles contained in the Wisconsin Constitution, which are implicit, more hiberally than those states with express separation of powers provisions. ${ }^{242}$ In Wisconsin, sharing of powers between the legislative and executive branches is acceptable so long as it does not disturb "the balance between the three branches of government," interfere with "their respective independence and integrity," or cause "concentration of unchecked power in the hands of any one brancl.." ${ }^{243}$ The court reasoned that tlie process did not violate Wisconsin's bicameralism and presentment provisions because "only the formal bicameral enactment process coupled with executive action can make permanent a rule suspension."244

Although the challenged Wisconsin process is more tempered than Idalio's, and the Supreme Court decision is much more circum-

238. See WIS. STAT. ANN. \$227.26 (West 1994). The grounds for suspending a rule in Wisconsin at the time included: absence of statutory authority; an emergency relating to the public health, safety, or welfare; a failure to comply with legislative intent; a conflict with state law; a change in circumstance since enactment of the law upon which the rule is based; arbitrariness and capriciousness; or imposition of an undue hardship. See id. §227.19(4)(d).

239. See id. $\$ 227.26(\mathrm{f})$.

240. Id. $\S 227.26(2)(i)$. Article V, $\S 10$ of the Wisconsin Constitution authorizes the Governor to veto legislation. WIS. CONST. art. V, § 10.

241. See Martinez v. Department of Indus., Labor \& Human Relations, 478 N.W.2d 582, 586-87 (Wis. 1992). In an advisory opinion, the New Hampshire Supreme Court, expressed some agreement with this view. See Opinion of the Justices, 431 A.2d 783, 789 (N.H. 1981) (declaring unconstitutional proposed legislation that would require agency rules to be submitted to a standing committee in each house of the legislature, but stating that a committee might be permitted to temporarily suspend a rule when the legislature is not in session to allow the legislature time to enact a bill).

242. See Martinez, 478 N.W.2d at 587.

243. Id. at 585 .

244. Id. at 586. 
spect, it is still doctrinally problematic, and thus probably cannot be generalized. According to Arthur Bonfield:

The reasoning and result of this Wisconsin case are questionable, since a temporary suspension amounts to a change in the law for the period in question without satisfaction of the bicameralism and the presentment requirements of the state constitution. Furthermore, the lack of express separation of powers provisions in the Wisconsin Constitution does not appear to justify different results in this cases as compared to the many state cases . . . that hold state legislative vetoes of various kinds invahd under their state constitutions because the Wisconsin Constitution's structure seems to incorporate in other ways, as the court in this case recognized, the same separation of powers principles contained in the more exphcit constitutional provisions of other states. $^{245}$

While the court attempted to address some of Bonfield's concern about changing law by suggesting that Wisconsin, like Idaho, recognizes a distinction between rules, which merely liave the force and effect of laws, and legislation, which is always subject to bicameral passage and presentment, this distinction is not universally accepted by state or federal courts. ${ }^{246}$

A message one might take from the 1997 decisions in Missouri and Michigan, as well as the doctrinal weight of other state court decisions that have addressed this issue, is that the future of legislative rules review-particularly where there is a veto and the state lias no explicit constitutional autliorization-is bleak. This is consistent with Bonfield's description of the doctrine, but the story in practice may not be quite that simple. Some state court opinions, such as those in Idaho and Wisconsin, endorse strong legislative oversight. In other states, however, informal factors related to the politics of state legislatures may lead to underenforcement of this separation of powers limitation.

As an illustration of the underenforcement of constitutional restrictions on legislative oversight of rulemaking, consider a recent challenge in North Carolina. Like Michigan and Missouri, North

245. ARTHur EARl Bonfield, State AdMINISTRative Rule Making $\S 8.3 .2(\mathrm{c})$, at 192 (Supp. 1993).

246. For example, a different doctrinal tact that may bring about the same result is to define rulemaking as an executive function. For instance, Kansas distinguishes between the promulgation of rules and regulations, which is "essentially executive or administrative in nature, not legislative" and the modifying or revoking of rules, which is "essentially legislative." State ex rel. Stephan v. Kansas House of Representatives, 687 P.2d 622, 635, 638 (Kan. 1984). In addition, as is noted above, Michigan defines rulemaking as an executive function. See supra note 223 and accompanying text. 
Carolina recently faced a challenge to its Rules Review Commission, an interesting entity comprised of citizens appointed by the legislature to review rules. In 1995, the North Carolina legislature amended its APA to extend the review authority of its Rules Review Commission ("Commission"), originally created in 1978, as well as the power of its legislature. The Commission, an eight member independent "citizens" commission appointed by the North Carohna legislature, now has veto power over agency rules. If the Commission does not approve an agency rule, the rulemaking process stops and the rule cannot go into effect. The grounds for vetoing rules include vagueness, lack of authority, and lack of necessity to carry out legislative intent. The Commission, which meets once a month, is not subject to the restrictions on lobbying or ex parte contacts that normally apply to administrative agencies. ${ }^{247}$

Between November 30, 1995, the date the 1995 amendments became effective, and Summer 1996, approximately 150 rules went through this process. ${ }^{248}$ The vast majority of rules have been approved without controversy. ${ }^{249}$ However, the Commission has used its authority to veto several controversial rules, sometimes in response to political opposition to the rules. For example, in July 1996, the Commission vetoed wetlands rules proposed by the state Environmental Management Commission because the Commission beheved the rules were vague and that the agency was without the statutory authority to adopt them, despite the state Attorney General's opinion to the contrary. ${ }^{250}$ More recently, the Commission vetoed a certificate-ofneed process for open-heart surgery centers, opposed by large health care interests in the state, and rules restricting sewage from hogs, opposed by the strong farming interests in the state. In both instances, representatives of those interests opposed to the rules made political appeals directly to the Commission. ${ }^{251}$

In addition, under the 1995 amendments, a North Carolina legislator may stop the agency rulemaking process by filing a bill to stop the process within 30 days of the beginning of the legislative session. Once such a bill has been filed, the agency rule cannot take effect until the bill passes, the bill is killed, or the session ends with-

247. See N.C. GEN. STAT. § 150B-21.12(d) (1995).

248. This discussion is based on Jack Betts \& Maria Henson, Above the Law: How eight unelected citizens wield the power to stop state government in its tracks, THE CHARLOTTE OBSERVER, Nov. 24, 1996, at C1.

249. See id.

250. See id.

251. See id. 
out the bill passing. ${ }^{252}$ The North Carolina process was challenged in 1997 on separation of powers grounds by several hospitals that were open-heart surgery certificate-of-need apphicants. ${ }^{253}$ The case settled, laying the issue at rest in North Carolina for the time being. ${ }^{254}$

Like North Carolina, many other states have committee veto provisions that allow committees to effectively hold captive administrative rules without full legislative and gubernatorial consideration and thus, under a strict application of Chadha's formalistic analysis, raise separation of powers problems. Pennsylvania's current review process allows a legislative committee to bar pubhication of rules to which it objects. ${ }^{255}$ In addition, Ohio and Oklahoma's legislative review processes allow concurrent resolution veto of administrative rules that fail to comply with specific criteria, even though neither state's constitution explicitly authorizes unilateral legislative action. ${ }^{256}$

Even states that do not allow a committee to effectively "veto" or "suspend" agency rules include in their legislative review process some requirements that are constitutionally problematic under Chadha-like formatistic application of separation of powers jurisprudence. Following Chadha's analysis, the recent Missouri case, Coalition for the Environment, suggests that a mandatory twenty-day waiting period pending committee review is constitutionally suspect. ${ }^{257}$ Several states, including Pennsylvania, ${ }^{258}$ Alabama, ${ }^{259}$

252. See N.C. GEN. STAT. § 150B-21.3(b) (1995).

253. See Betts \& Henson, supra note 248 at C1.

254. More recently, the North Carolina Pharmacy Board has filed a challenge to the Rules Review Commission's rejection of the Board's rule limiting pharmacists' work shifts. See Carol Ukens, "North Carolina Board Headed to Court Over R.Ph. Workload Rule," DRUG TopICS, Feb. 1, 1999 at 41 (available on LEXIS);

255. See 71 PA. CONS. STAT. ANN. $§ 745.6$ (West 1990) (Supp. 1999) (allowing legislative committee's disapproval of proposed regulation to bar its promulgation, unless the Attorney General certifies the regulation is necessary for public health, safety, or welfare, or otherwise required by law). Pennsylvania's objection process contains a review proposal that allows full legislative consideration of regulations that have been objected to, but this process is not mandatory. If an agency does not avail itself of this process within 40 days, the objected-to rule is withdrawn. See id. $\S 745.7$.

256. See OHIO Rev. Code ANN. § 101.35 (West Supp. 1994 (Supp. 1999)); OKLA. STAT. ANN. tit. 75, § 308 (West 1995) (Supp. 1999).

257. See Missouri Coalition for the Env't. v. Joint Comm. on Admin. Rules, 948 S.W.2d 125, 136 (Mo. 1997) (en banc) (observing statute is unconstitutional insofar as it allows a joint committee "to suspend publication and promulgation [of an agency's] final orders of rule making for up to twenty days while the JCAR reviewed such rules").

258. See 71 PA. CONS. STAT. ANN. $§ 745.5$ (West 1990) (Supp. 1999) (suspending rules temporarily pending review committee actions).

259. See ALA. CODE. $\S 41-22-23(b)$ (Supp. 1998) (providing that a rule disapproved by legislative committee "shall be suspended until the adjourument of the next regular session of 
Alaska, ${ }^{260}$ Illinois, ${ }^{261}$ Iowa, ${ }^{262}$ Maine, ${ }^{263}$ and Nevada ${ }^{264}$ presently allow the committee review process or committee objection to delay the rulemaking process. ${ }^{265}$ In addition, in several states committee objection has the effect of shifting the burdens in a rule challenge proceeding ${ }^{266}$ or works to estabhsh presumptive or conclusive evidence of legislative intent. ${ }^{267}$ Although the constitutional problems with such provisions-at least on a formalistic reading of separation of powershave on occasion been noted, ${ }^{268}$ to date courts have not held such provisions, standing alone, unconstitutional. Thus, in many states general legislative review mechanisms inconsistent with Chadha separation of powers analysis apply to agency rulemaking.

the legislature following the date of disapproval and suspension of the committee or until the legislature shall, by joint resolution, revoke the suspension of the committee").

260. See ALASKA STAT. § 24.20.445(a) (Michie 1998) (allowing two-thirds vote by committee when legislature is not in session to suspend the effectiveness of the adoption of a regulation until thirty days after legislature reconvenes).

261. See 5 Ill. CoMP. STAT. ANN. 100/5-110, 100/5-115, 100/5-120 (West Supp. 1999) (allowing committee objection to delay rulemaking process).

262. See IOWA CODE ANN. § 17A.8 (West Supp. 1999) (allowing two-thirds vote by committee when legislature is not in session to "delay the effective date of a rule until the adjournment of the next regular session of the general assembly").

263. See ME. REV. STAT. ANN. tit. 5, pt. 18, ch. 375, subch. II-A (West Supp. 1998) (delaying adoption of rules pending consideration by legislature).

264. See NEV. REV. STAT. ANN. § 223B.0675 (Michie Supp. 1997) (allowing committee objection to delay agency adoption of regulations until thirtieth day of the next regular legislative session). Nevada appears to have express constitutional authorization for this procedure. See NEV. CoNST. art. 3, §1 (1998).

265. Missouri's new legislative review process, amended in reaction to Missouri Coalition for the Environment, also delays the implementation of rules until the expiration of thirty days of a legislative session. See MO. ANN. STAT. $\$ 536.028$ (West Supp. 1999).

266. See N.H. REV. STAT. ANN. § 541-A:13.VI (1997) (following committee objection agency bears the burden of estabhishing rule's validity); N.D. CENT. CODE § 28-32-03.3 (Supp. 1999) ("After the filing of a committee objection, the burden of persuasion is upon the agency in any action for judicial review or for enforcement of the rule.... If the agency fails to meet its burden of persuasion, the court shall declare the whole or portion of the rule objected to invalid and judgment must be rendered against the agency for court costs."); VT. STAT. ANN. tit. $3, \S 842$ (1996) (legislative committee objection results in agency burden of proof that rule is within agency's authority, consistent with the intent of the legislature, and not arbitrary). Similarly, under the 1981 Model State Administrative Procedure Act, legislative review committee objection shifts to an agency the burden of establishing "that the whole or portion of the rule objected to is within the procedural and substantive authority delegated to the agency." MODEL STATE ADMINISTRATIVE PROCEDURE ACT § 3-204(d)(5) (1981).

267. See KY. REV. STAT. ANN. § 13A.032 (Michie 1996) (allowing committee objection to estabhish prima facie case of legislative intent in pending rule proceedings, and also estabhishing autbority for committee to institute rule challenge in circuit court); MONT. CODE ANN. $\S \S 2-4$ 403, 2-4-404 (1997) (allowing committee to poll members of the legislature; establishing conclusive evidence in a rule challenge proceeding that the rule is contrary to legislative intent).

268. In Eklund v. Eklund, North Dakota Supreme Court Justice Sandstrom observed that delegating to a legislative committee the authority to shift the burden of persuasion in court cases involving administrative rules is constitutionally problematic on Chadha grounds. Eklund v. Eklund, 538 N.W.2d 182, 189 (N.D. 1995) (Sandstrom, J., concurring). 
Many, but not all, states endorse formal restrictions on the legislative veto that are similar to Chadha. Regardless of formal restrictions on legislative oversight, informal institutional factors may lead to underenforcement of these restrictions in many states. Both formal, rule-based doctrines and informal, micropolitical factors influence how separation of powers works to constrain the participation of state legislatures in agency rulemaking.

\section{STATE CONSTITUTIONAL INTERPRETATION AND INSTITUTIONAL DESIGN}

There are many strong similarities between federal and state separation of powers doctrines. However, some state approaches to separation of powers diverge from the federal approach, much in the same manner as Antifederalist and Federalist separation of powers ideals. As I suggest in Table 2, federal and many state judicial approaches differ, in doctrine and enforcement, in the contexts of nondelegation and limitations on legislative oversight of rulemaking.

Table 2:

Comparison of Federal and State Approaches

\begin{tabular}{|l|l|l|}
\hline $\begin{array}{l}\text { Enforcement of Separation } \\
\text { Of Powers Doctrine }\end{array}$ & Nondelegation Limits & $\begin{array}{l}\text { Limits on Unilateral Leg- } \\
\text { islative Oversight }\end{array}$ \\
\hline Federal (more Federahst) & $\begin{array}{l}\text { Weaker (Davis' proce- } \\
\text { dural safeguards) }\end{array}$ & Stronger (since Chadha) \\
\hline Stronger (mejection of & $\begin{array}{l}\text { Weaker (underenforcement } \\
\text { in states such as North } \\
\text { Carolina; doctrinal diver- } \\
\text { gences as in Idaho, Wiscon- } \\
\text { sin; many committee } \\
\text { waiting periods and burden } \\
\text { shifting that are suspect } \\
\text { under Chadha) }\end{array}$ \\
\hline
\end{tabular}


While the federal approach is consistent with Federahist separation of power principles, the approach of many states is Antifederalist in spirit. Like the Antifederalists, many states endorse strict separation of functions, as in the strong nondelegation doctrine, or excuse legislative supremacy, as is the case with underenforcement of Chadha-like restrictions on the legislative veto. ${ }^{269}$ At the same time, with the exception of Chadha's formalism (but not Chadha's result), Antifederalist ideals are incompatible with the approach of federal courts.

As I will argue in this Part, many states embrace Antifederalist principles, but the interpretive practice of state constitutional law has not adequately acknowledged the principles behind this legacy, nor has it provided an adequate explanation why they might be desirable. Serious study of the unique institutional design of state systems of governance, I suggest, is a necessary predicate to the development of an independent theory of state separation of powers. These institutional factors can explain doctrinal nuances and enforcement levels in state separation of powers jurisprudence and should be addressed explicitly by state courts addressing separation of power issues, especially where they rely on or reason from extrajurisdictional authorities.

\section{A. The Limits of Common American Heritage, Textual, and Character Interpretivism}

As an exercise in judicial interpretation, state constitutionalism differs significantly from areas such as commercial or property law. There are reasons for some strong degree of consistency in the commercial and property law contexts, among them the promotion of uniformity and certainty in private transactions. Yet state constitutions reflect a variety of historical, institutional, and pohtical variance. ${ }^{270}$ At the same time, American law schools, which teach consti-

269. Stanley Friedelbaum, in his recent survey of state separation of powers doctrines affecting judicial-political and executive-legislative branch relations, reaches a similar conclusion. See Stanley H. Friedelbaum, State Courts and the Separation of Powers: A Venerable Doctrine in Varied Contexts, 61 ALB. L. REV. 1417, 1457 (1998) (observing that state doctrine is more "conventional" and "less likely to embody the permissiveness characteristic of federal rulings").

270. Mel Eisenberg has identified several values reinforced through articulation of generic private common law principles, but stops short of suggesting that these values are also reinforced through elucidation of public common law. MELVIN A. EISENBERG, THE NATURE OF THE COMMON LAW (1988). His recent work suggests that the emergence of "national" common law is consistent with common law decisionmaking within a federahst system. See Melvin A. Eisenberg, Is There a National Common Law?, 27 FLA. ST. U. L. REV. (forthcoming 1999). 
tutional law almost entirely in the context of federal court cases interpreting the U.S. Constitution, reinforce reliance on federal judicial authority in interpreting constitutions. Most American lawyers think of constitutional law in terms of the categories and doctrines that emanate from federal cases. The natural temptation of lawyers and state law judges addressing issues of state constitutional law is to rely on federal authority.

Despite this temptation, a court's degree of reliance on federal authority in addressing constitutional law often will-and should-vary depending on the nature of the issue it is addressing. If a state court is addressing an issue to which both the U.S. Constitution and the applicable state constitution have applicable clauses-such as free speech, free exercise and nonestablishment of religion, or equal protection-then the court has some obligation to use the federal authority to define the minimum applicable threslold concerning individual rights. ${ }^{271}$ Beyond this legal obligation, state courts in this context retain a large degree of interpretive discretion in addressing issues of constitutional law. In other contexts-largely issues of structure, such as separation of powers-federal constitutional authority does not, as a legal matter, compel a minimum result. ${ }^{272}$ Here, state courts liave the full range of interpretive discretion at their disposal as they grapple with issues of constitutional law.

In exercising this discretion, state courts can turn to a variety of methods to assist in their interpretive task. The most common methods used by state courts are appeals to common American values, textual, or character-based interpretive approaches. In the context of separation of powers jurisprudence, none of these interpretive approaches is an adequate tool for addressing the problems state courts face.

\section{The "Common American Heritage" Approach}

There are serious limits to any interpretive approach that views state constitutionalism as a part of a "common American heritage" witl the federal system. ${ }^{273}$ This heritage is not always a shared

271. For a discussion of the incorporation doctrine, see LAURENCE H. TRIBE, AMERICAN CONSTITUTIONAL LAW 772-77 ( $2 \mathrm{~d}$ ed. 1988).

272. See supra notes 92.95 and accompanying text (discussing the Guarantee Clause).

273. On this view, see Gardner, supra note 4, at 1289 (suggesting that state courts are entitled to part company with the U.S. Supreme Court "for no other reason than, in the state court's view, the Supreme Court has gotten it wrong'); see also James A. Gardner, What Is a 
one, particularly in the context of separation of powers, which was a highly contested doctrine at the time of the founding. ${ }^{274}$ In their results, many state cases endorse Antifederalist ideals that contrast sharply with the Federalist ideals in the U.S. Constitution. Despite this, in rationale, many state cases invoke a common American heritage interpretive method, duplicating the approach of U.S. Supreme Court separation of powers decisions, such as Chadha.

For example, in Missouri Coalition for the Environment $v$. Joint Committee on Administrative Rules, the Missouri Supreme Court did nothing more than mimic the U.S. Supreme Court's Chadha opinion, applied in the context of Missouri's Constitution. ${ }^{275}$ While Chadha's formalism provides a fairly simple answer to the constitutionality of committee suspension of agency rules, it skirts the distinct institutional practice of state legislative oversight.

This lockstep approach is particularly misleading where nondelegation issues are addressed. For example, the Hawaii Supreme Court, in upholding the constitutionality of a statute granting the state Public Service Commission the authority to grant interim rate increases, stated: "The 'just and reasonable' standard has been upheld as constitutionally permissible, even thougl no specific formula for determining that which is just and reasonable has been statutorily set."276 The court relied on federal authority for its conclusion and did not independently assess the constitutionality of the statute under Hawaii's Constitution or case law.

Other Hawaii cases also endorse a lockstep approach. In State $v$. Bernades, the Hawaii Supreme Court addressed whether state sentencing guidelines violate separation of powers under Hawaii's Constitution. ${ }^{277}$ The Court ruled that the guidelines did not violate "the separation of powers doctrine under the Hawaii and United States Constitutions," a direct-but mysterious-reference to federal

State Constitution?, 24 RUTGERS L.J. 1025, 1044-54 (1993) (arguing that state constitutions are not the embodiment of independent political values, but instead are safeguards that reinforce national political values where the federal government has failed to do so); Kahn, supra note 6, at 1166 (noting state courts need not rely on "unique state sources" to support interpretations, but should attempt "to realize for their own communities the ideals that are the common heritage of the nation").

274. See William B. Gwyn, The Indeterminacy of the Separation of Powers in the Age of the Framers, 30 WM. \& MARY L. REV. 263, 265-66 (1989).

275. Missouri Coalition for the Env't. v. Joint Comm. on Admin. Rules, 948 S.W.2d 125 (Mo. 1997) (en banc). The reasoning of the opinion is discussed supra notes 194-210 and accompanying text.

276. In re Kauai Elec. Div., 590 P.2d 524, 535 (Haw. 1978).

277. State v. Bernades, 795 P.2d 842 (Haw. 1990). 
law in a case where state law controls. ${ }^{278}$ No effort was made by the court to address possible differences in these independent sources of separation of powers. Such a lockstep approach ignores the evidence, historical and contemporary, that would suggest state constitutions endorse fundamentally different principles of separation of powers than the U.S. Constitution. ${ }^{279}$

\section{The Textual Approach}

Another, far more popular, method for resolving issues of interpretive discretion in state constitutional jurisprudence is to look to the constitutional text. ${ }^{280}$ This is precisely what the Florida Supreme Court did in Askew v. Cross Key Waterways, a modern Florida case addressing Florida's nondelegation doctrine. ${ }^{281}$ There, the court reasoned that the text of Florida's strict separation of powers clause dictated Florida's rigorous approach to nondelegation. Florida's Supreme Court was correct to observe that the U.S. Constitution differs in text from Florida's Constitution. But its analysis should not have ended there: Florida's separation clause differs hittle in text from many states that have adopted a moderate or weak approach to the nondelegation issue. Constitutional text provides little assistance in explaining the various approaches to separation of powers issues vertically, between the U.S. and the states, or horizontally, among the many states. Thus, though perhaps tempting to state court judges, textualism fails as an interpretive method in the separation of powers context because it does not explain differences in result between systems with similar separation of powers clauses in their constitutions.

278. Id. at 845. Hawain is not the only state to endorse the lockstep approach. See In re Adoption of Regulations Governing the State Health Plan, 621 A.2d 484, 488 (N.J. Super. Ct. App. Div. 1993) (relying almost exclusively on federal case law to uphold a delegation to a state agency).

279. Daniel Elazar is perhaps the most consistent advocate of the theory that state constitutions are unique in their approach to separation of powers. See ELAZAR, supra note 21, at 10915 (arguing that state constitutions endorse Whig notions of rigid separation of powers and legislative supremacy, whereas the U.S. Constitution is grounded in a notion of mixed powers). See also LUTZ, supra note 21, at 69 (noting distinction between federal and state constitutions, but suggesting that the distinction should not be pushed too far).

280. See, e.g., Hans A. Linde, Are State Constitutions Common Law?, 34 ARIz. L. REv. 215, 220-21 (1992) (criticizing the New Jersey Supreme Court's use of due process and equal protection principles despite the absence of such provisions in the text of the New Jersey Constitution).

281. Askew v. Cross Key Waterways, 372 So. 2d 913 (Fla. 1978). The case is further discussed supra notes 135-39 and accompanying text. 


\section{The "Political Culture" Approach}

The new judicial federalism provides another, perhaps more attractive interpretive method. According to the advocates of this theory, the "political culture" of a region or locality should inform state constitutional interpretation. For example, as the political scientist Daniel Elazar has suggested, regional differences have had an impact on the development of state constitutions. ${ }^{282}$ As Elazar's empirical research suggests, states are diverse with respect to whether their political culture is primarily individuahstic, moralistic, or traditionalistic. ${ }^{283}$

The objections to such an interpretive practice are many. ${ }^{284}$ To begin, the extent to which this practice invites judges to invoke their own understanding of conventional morality for their locality or region places a judge in the difficult position of reading the state's cultural pulse while also providing little hope for common experimentation between states.

Even though there may be cognizable regional or statewide differences in public attitudes regarding the division of power between the legislature and executive, it does not follow that state judicial opinions slould explicitly reflect these differences in interpretive practices. At its extreme, this would require courts to identify cultural values, inviting judges to take into account citizen attitudes about governmental institutions, such as the confidence polls for a given governor. Over time, this might lead to large swings in a state's separation of power jurisprudence, based on pohitical attitudes and the political composition of courts. ${ }^{285}$ Thus, to the extent state courts do embrace this interpretive method in the separation of powers

282. See ELAZAR, supra note 21, at 114. For academic lawyers and jurists endorsing this position, see supra note 3 .

283. See DANIEL J. ElazAR, AMERICAN FEDERALISM: A VIEW FROM THE STATES 114-26 (2d ed. 1972). Following Robert Putnam's well known examination of civic culture and democracy in Italy, more recent empirical work attempts to construct indices for measuring civicness and governmental performance, reporting a wide divergence among the states. See Tom W. Rice \& Alexander F. Sumberg, Civic Culture and Government Performance in the American States, PUBLIUS, Winter 1997, at 99.

284. See, e.g., Daniel Gordon, Superconstitutions Saving the Shunned: The State Constitutions Masquerading as Weaklings, 67 TEMP. L. REV. 965, 970 (1994) (urging deemphasis of role of state constitntions as repositories of fundamental values); Hans E. Linde, E PluribusConstitutional Theory and State Courts, in DEVELOPMENTS IN STATE CONSTITUTIONAL LAW 273, 294-95 (Bradley D. McGraw ed., 1985); Hans A. Linde, State Constitutions Are Not Common Law: Comments on Gardner's Failed Discourse, 24 RUTGERS L.J. 927, 932 (1993).

285. One recent commentator, challenges the community conception of state identity as giving "rise to pointless, indeed often silly, debates about state character." Robert A. Schapiro, Identity and Interpretation in State Constitutional Law, 84 VA. L. REV. 389, 393 (1998). 
context, it is unlikely that any serious theory of state separation of powers will develop. Each state will simply have taken its own path in understanding its separation of powers jurisprudence, paying little or no attention to developments, similarities, and differences elsewhere. For this reason, the political cultural method of interpretation, if used at all, might best be confined to instances where a state court is defining rights, not governmental structure. ${ }^{286}$

This leads to a final objection to the political culture approach to state constitutional interpretation. At its worse, it results in a type of cultural relativism, suggesting courts identify sources of and merely describe culture rather than provide reasons to support their decisions. Even if the worst does materialize in result-allowing unaccountable and extreme interpretation of issues involving human rights-the political culture interpretive method does not require state courts to justify their constitutional decisions in a manner that appeals to courts outside of a given jurisdiction. In this sense, it thwarts the new judicial federalism ideal of experimental democracy, ${ }^{287}$ and thus collapses on its own weight.

\section{B. Institutional Design, the Legacy of Antifederalist Separation of Powers Ideals, and State Constitutional Interpretation}

The divergence between the federal approach and that of many states may be explained by reference to institutional design differences between the systems of governance. There are many institutional similarities between federal and state systems of governance. At the same time, the institutional design features of many states hold promise to explain differences in jurisprudential approaches to separation of powers. While it would be a mistake to exaggerate the influence of these institutional design features on constitutional doctrine, they can go far towards explaining doctrinal nuances and enforcement levels in state separation of powers.

286. Cf. Robert A. Schapiro, Contingency and Universalism in State Separation of Powers Discourse, 4 ROGER WILLIAMS U. L. REV. 79, 95 (1998) ("States may have developed individual cultures giving rise to enhanced appreciation for free expression or privacy, but the basic mechanisms of governmental power have not changed since the framers erected the federal constitutional system.").

287. "It is one of the happy incidents of the federal system that a single courageous State may, if its citizens choose, serve as a laboratory; and try novel social and economic experiments without risk to the rest of the country." New State Ice Co. v. Liebemann, 285 U.S. 262, 311 (1932) (Brandeis, J., dissenting); cf. Rodriguez, supra note 9 (holding out hope for a "trans-state" constitutionahsm). 
1. Institutional Design and Nondelegation Doctrine

Institutional analysis provides some explanation for the difference between federal and state nondelegation doctrine and enforcement levels. Since the time of the Founding, commentators have observed that the state legislative process is more prone to faction than the federal lawmaking process. During the Founding, it is reported, "[s]tate experience . . . contributed, nothing more strongly, to discredit the whole idea of the sovereign legislature, [than] to bring home the real meaning of limited government and coordinate powers." ${ }^{288}$ The Federalists, responding to the notions of legislative supremacy in Whig and Antifederalist political science, endorsed a blended notion of separation of powers that provides for limits on legislative authority but, as has been suggested, ${ }^{289}$ Federalist political science is consistent with a relaxed nondelegation doctrine.

In many states, Antifederalist principles are alive and well and the strong nondelegation doctrine, as it has been fashioned by state courts, acts as one limitation on the exercise of faction to capture lawmaking power. In strong nondelegation states, courts evaluate whether state legislatures have specific substantive standards to guide agency discretion in exercising delegated power. These standards himit agency discretion and also provide a meaningful measure for courts to apply in exercising judicial review. Moderate nondelegation states require, at a minimum, some legislative statement of policy, and some require a statement of policy along with procedural safeguards. Without such standards, as compared to federal agencies, state agencies are more prone to capture by powerful and wellorganized interest groups, given the lower barriers to mobihzation at the state level. ${ }^{290}$

Key institutional differences between the federal and most state legislative systems suggest that the problem of faction is much stronger at the state level. One difference is that state legislatures are in session for shorter periods than the U.S. Congress, and thus state legislative assemblies are likely to have less familiarity with issues and less time to evaluate bills than members of Congress. For example, the Texas Legislature sits for 120-day sessions once every

288. THACH, supra note 26 , at 52.

289. See supra Part II.A.

290. State legislatures, however, may also be more prone to faction than the U.S. Congress, as is discussed below. The Antifederalist principles of separation of powers seem to ignore legislative faction. 
two years. ${ }^{291}$ Florida has a sixty day session, only about forty five of which are working days; New Mexico's sessions are only sixty calendar days in odd-numbered years, while in even-numbered years sessions are hmited thirty days and the focus is mainly on fiscal matters. ${ }^{292}$ Many other state legislatures have similarly short sessions. ${ }^{293}$ A short legislative session might make delegation to an executive branch more practical, but most state courts have not endorsed delegation for this efficiency purpose. Instead, state courts adhering to a strong nondelegation doctrine trade off the potential efficiencies associated with delegation to guard against faction and ensure that the legislature, rather than agencies, makes key policy decisions.

Other institutional design features also illustrate how faction is more likely to exacerbate state agency decisionmaking and why a nondelegation doctrine in the states may be more effective at minimizing the effects of faction. Although in many states legislative staff is extensive, most states provide members of the legislature little staff assistance in exercising their lawmaking function. ${ }^{294}$ Also, because of geographic proximity and economic and cultural similarities, the organization and mobilization of interest groups, such as farming or tobacco interest groups, is much easier at the state than the national level. Given lower costs of organization and mobilization, such interest groups are more hikely at the state than federal level to influence the political process. ${ }^{295}$ Aware of this phenomenon at the time of the Founding, Madison wrote that " $[t]$ he influence of factious leaders may kindle a flame within their particular States, but will be unable to

291. See TEX. CONST. art. III, §5; see also Bruff, supra note 16, at 1346 (discussing potential impact of this institutional feature on Texas nondelegation doctrine).

292. See Alan Rosenthal, The Decline of Representative Democracy: Process, PARTICIPATION, AND POWER IN STATE LegislatuRES 128 (1998).

293. See The Council of State Governments, THE BooK of THE STATES 64-67 (1998-99 ed.); see also Alan Rosenthal, The State of State Legislatures: An Overview, 11 HoFSTRA L. REv. $1185,1187-1192$ (1983).

294. See Alan ROSenthal, Legislative Performance in the States: Explorations of COMMITTEE BEHAVIOR 149-51 (1974).

295. For over thirty years, economists and political scientists have recognized and explored the role of interest groups in influencing the political process and its outcomes. See, e.g., GeORge J. Stigler, The Citizen AND the STATE: EsSAYS ON REgulation (1975); George J. Stigler, The Theory of Economic Regulation, 2 BELL J. ECON. \& MGMT. SCI. 3 (1971). The insights of economists, such as Stigler, have been apphed by modern pohtical scientists writing in the field of public choice. See generally MASHAW, GREED, CHAOS, \& GoverNANCE, supra note 47; Jim Rossi, Public Choice Theory and the Fragmented Web of the Contemporary Administrative State, 96 MrCH. L. REV. 1746 (1998) (book review). 
spread a general conflagration through the other States." ${ }^{296}$ Madison derided the tendency of state legislators to sacrifice the interests of their state for the particular and separate views of their counties and locahties. $^{297}$ Faction makes capture of the state legislative processand particularly delegation to an agency controlled by a small but powerful constituency-more likely. ${ }^{298}$ Consistent with the ideals of Whig and Antifederalist constitutionahism, modern state legislatures undergo a high degree of turnover vis-à-vis the U.S. Congress, ${ }^{299} \mathrm{con}$ tributing to the likelihood that the state legislative process will produce laws that are the product of highly-organized special interest groups representing a small but vocal group of the legislature's constituency.

Of course commentators have argued that, at the federal level, delegation of decisionmaking authority to agency decisionmakers can have pro-democratic effects, in part because the unitary executive provides some degree of streamlined accountability to the President's Office for agency policy decisions. ${ }^{300}$ Even though the President is not aware of most agency decisions-especially minor ones-the President is often held accountable by the media, Congress, and the public at large for the positions of agencies within the executive branch. Many suggest that the U.S. Constitution envisions a "unitary executive."301

Although a few states follow this approach, ${ }^{302}$ most states do not have a unitary executive. ${ }^{303}$ In Texas, for instance, the long ballot provides

296. The Federalist No. 10 (James Madison). See also WoOd, supra note 13, at 550-51 (noting purpose of separation of powers for Federalists was to avoid legislative usurpation and oppression).

297. See JOSEPH M. BESSETte, The MILD VOICE OF REASON 26 (1994).

298. See Jim Rossi, Participation Run Amok: The Costs of Mass Participation for Deliberative Agency Decisionmaking, 92 NW. U. L. REV. 173, 184-85 (1997).

299. See ROSENTHAL, supra note 292 , at $67-80$ (describing the influence of term limits and other factors on the degree of professionalism in state legislatures).

300. See supra notes $48-49$ and accompanying text.

301. See Steven G. Calabresi \& Kevin H. Rhodes, The Structural Constitution: Unitary Executive, Plural Judiciary, 105 HARV. L. REV. 1153, 1155 (1992). See generally Saikrishna Bangalore Prakash, Note, Hail to the Chief Administrator: The Framer's and the President's Administrative Powers, 102 YALE L.J. 991 (1993).

302. The Pennsylvania and Virginia executives are almost entirely unitary, providing for general election of the Governor, Lieutenant Governor, and Attorney General and few other officers. See PA. CONST. art. IV, $\S \S 1,4.1,5,18$ (providing for the election of the Governor, Lieutenant Governor, Attorney General, Auditor General, and State Treasurer); VA. CONST. art. V, $\S \S 2,13,15$ (providing for election of the Governor, Lieutenant Governor, and Attorney General). Some of the more recent state constitutions also provide for a unitary executive; see also ALASKA CONST. art. III, $\S \S 3,8$ (only elected officials are Governor and Lieutenant Governor, who run together on a single ticket); HAW. CONST. art. V, $\S 6$ (providing heads of all principal departments will be nominated by the Governor and confirmed by the Senate); lOWA CONST. art. IV, $\S \S 1-4,22$ (similar to Alaska, but also providing for election of Secretary of State, Auditor, and Treasurer); MD. CoNST. art. II, $\$ \S 10,18,22$ (similar to Hawaii); N.J. CoNST. art. $\mathrm{V}, \S 4$, I 3,4 (similar to Hawaii). 
for the separate election of officials such as the lieutenant governor, the attorney general, the comptroller, the treasurer, and the land commissioner. ${ }^{304}$ Florida also has a plural executive branch, providing for separate and independent election of a Governor and an Attorney General, a Commissioner of Agriculture, a Commissioner of Education, a Comptroller, an Insurance Commissioner and Treasurer, and a Secretary of State. ${ }^{305}$ Alabama provides for separate statewide election of a Governor, Lieutenant Governor, Attorney General, State Auditor, Secretary of State, State Treasurer, Superintendent of Education, and Commissioner of Agriculture and Industries. ${ }^{306}$ Most other states have similar provisions providing for independent election of statewide executives, although the listing of executives varies from state to state, ${ }^{307}$ and a handful of states with older constitutions provide for election of some executive officers by the legislature. ${ }^{308}$ Among states that deviate from the unitary executive model in their constitutions, the governor's power to lead and supervise bureaucracy

303. All but four states provide for independent election of lower (or co-equal) executive branch officials, and many provide for popular election to executive offices. See THE COUNCIL OF STATE GOVERNMENTS, supra note 293, at 35-40. The plural executive branch is largely a result of turn-of-the century progressive constitutional reform. See Roger Kersh et. al., "More of $a$ Distinction of Words than Things": The Evolution of Separated Powers in the American States, 4 ROGER WILLIAMS U. L. REV. 5, 29-35 (1998).

304. See TEX CONST. art. IV, $\S \S 1,2$ (providing for statewide election of Attorney General, Comptroller of Pubhic Accounts, and Commissioner of General Land Office along with Governor and Lieutenant Governor; Secretary of State is appointed by Governor); see also Bruff, supra note 16 , at 1347 .

305. See FLA. CONST. art. IV, §§ 4, 5; see also Richard K. Scher, The Governor \& Cabinet: Executive Policymaking and Policy Management in THE FLORIDA PUBLIC POLICY MANAGEMENT SYSTEM: GROWTH AND REFORM IN AMERICA'S FOURTH LARGEST STATE 73 (Richard Chackerian, ed., 2d ed. 1998).

306. See ALA. CONST. art. V, §§ 112, 114-16.

307. See ARIz. ConST. art. V, § 1; ARK. CONST. art. VI, §§ 1, 3; CAL. CONST. art. V, § 11;

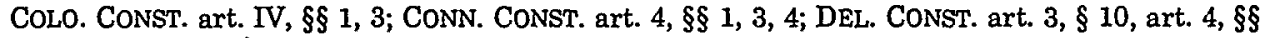
19, 21; GA. CONST. art. V, § III, I 1; IDAHO CONST. art. IV, § 1; ILL. CoNST. art. V, § 1; IND. CoNST. art. 6, § 1; KAN. CoNST. art. I, § 1; KY. CoNST. § 91; LA. CoNST. art. IV, § 3; MICH. ConsT. art. V, § 21; MINN. ConsT. art. V, § 1; MISS. ConsT. art. 5, §§ 133, 134; MO. CoNST. art. IV, § 17; NEB. ConsT. art. IV, § 1; NEV. Const. art. 5, § 19; N.M. ConsT. art. V, § 1; N.Y. CoNST. art. V, § 1; N.D. CONST. art. V, § 2; OHIO CONST. art. III, § 1; OKLA. CONST. art. VI, § 4; OR. CONST. art. VI, § 1; R.I. CONST. art. IV, § 1; S.C. CONST. art. VI, § 7; S.D. CONST. art. IV, § 7; UTAH CONST. art. VII, $\S 1$; VT. CONST. ch. II, $\S \S 43,47-49$; WASH. CONST. art. III, $\S \S 1,3 ;$ W. VA. CONST. art. VII, § 1; WIS. CONST. art. VI, § 1; WYO. CoNST. art. IV, § 11.

308. See ME. ConST. art. V, pt. $2, \S 1$, pt. $3, \S 1$ (legislative election of Secretary of State and Treasurer); MASS. CONST. pt. 2, Ch. 2, § IV, art. I, § 80 (legislative election of Secretary, Treasurer and Receiver General, Commissary General, Notaries Public, and Naval Officers); N.H. CONST. pt. 2, art. 67 (legislative election of Secretary of State and Treasurer); TENN. CONST. art. VII, $\S 3$ (legislative election of Treasurer or Treasurers, and Comptroller of the Treasury). 
is reduced, ${ }^{309}$ although political scientists observe great variations in the degree of reduced leadership and supervision. ${ }^{310}$ Regardless of the variations of degree across the various states, in most states the ability of a governor to oversee executive policymaking is weak relative to the U.S. President's. From an accountabihty perspective, this makes delegation more suspicious in the states than at the federal level.

Finally, regardless of procedural safeguards that may exist under state APAs-safeguards that might suffice for purposes of meeting Davis' nondelegation test-many states do not have the same degree of rigorous judicial review of agency rulemaking that is available under the federal APA. In Texas, the degree of judicial review of agency action varies significantly; sometimes, review is unavailable. ${ }^{311}$ In Florida, for example, arbitrary and capricious review of an agency's reasoning process, as is available under the federal APA, is not generally available in the course of judicial review. ${ }^{312}$ Bill Funk, in his 1991 survey of state rationality review, reports that only eight states follow the federal example of providing a statutory basis for judicial review of the rationality of rules. ${ }^{313}$ To the extent states lack rigorous judicial review, particularly of agency rulemaking, this exacerbates the oversight problem. As Harold Bruff has stated, "[a]bsent effective judicial review, an agency may be accountable to no one but itself." 314

Because of institutional design differences between the federal system and that of many states and the way these differences influence the possibihty of capture, state courts have reasons for endorsing a stronger version of the nondelegation doctrine than their federal counterparts. State legislatures, and often agencies, are more prone

309. An example is Florida. Richard Scher observes that, although Florida's Governor is historically weak in power relative to other state governors, reforms to budgetary power have strengthened the power of Florida's governor since 1968. See Scher, supra note 305, at 79.

310. See Thad L. Beyle, Governors, in Politics IN THE AMERICAN STATES 201 (Virginia Gray et al. eds., 5th ed. 1990); Joseph Schlesinger, The Politics of the Executive, in POLITICS IN THE AMERICAN STATES 210 (Herbert Jacob \& Kenneth N. Vines eds., 2d ed. 1971); Julia E. Ronbinson, The Role of the Independent Political Executive in State Governance: Stability in the Face of Change, 58 PuB. ADMIN. REv. 119 (1998).

311. See Firemen's \& Pohcemen's Civil Serv. Comm'n v. Blanchard, 582 S.W.2d 778, 779 (Tex. 1979).

312. See FLA. STAT. ANN. $§ 120.68(9)$ (West 1996). For recent modifications to burdens of proof and standards of review in rule validity challenges under Florida's APA, see Jim Rossi, The 1996 Revised Florida Administrative Procedure Act: A Rulemaking Revolution or CounterRevolution?, 49 ADMIN. L. REV. 345 (1997).

313. See William Funk, Rationality Review of State Administrative Rulemaking, 43 ADMIN. L. REV. 147, 154 (1991). For an argument against arbitrary and capricious review of rulemaking under state APAs, see Dave Frohnmeyer, National Trends in Court Review of Agency Action: Some Reflections on the Model State Administrative Procedure Act and the New Utah Administrative Procedure Act, 3 B.Y.U. J. PUB. L. 1 (1989).

314. Bruff, supra note 16 , at 1347 . 
to faction than the U.S. Congress or federal agencies, both because the costs of organizing and mobilizing local factions are lower and because state legislatures, in session for very limited terms, are not as effective as Congress at oversight. In addition, agencies are less accountable to an executive leader and judicial review of agency decisionmaking is much less rigorous than at the federal level.

Although there are some institutional reasons for enforcing the strong or moderate nondelegation doctrine at the state level-and these may have contributed to the continued adherence to Antifederalist principles-it would seem that state judges are inclined to the same institutional failures as their federal counterparts in implementing the nondelegation doctrine. As commentators have observed, one of the problems with the nondelegation doctrine is that courts are not capable of articulating a coherent and consistent nondelegation doctrine. ${ }^{315}$ Although many of these commentators view courts as possessing inherently pohtical traits, a proposition that is debatable, this critique of the nondelegation doctrine lias much support in the hiterature. ${ }^{316}$

State judges, thougl, may have different comparative institutional advantages within state systems of governance than their federal counterparts. Over forty states provide for popular election of state judges, a design feature that enhances the political accountability of state judges while decreasing their independence, as compared to their federal counterparts. ${ }^{317}$ In addition, many state courts have the constitutional authority to evaluate legislation more frequently than federal courts; thus, state courts may have more experience addressing the validity of legislative delegations than their federal counterparts. Ellen A. Peters, a Senior Justice of the Supreme Court of Connecticut, observed state separation of powers jurisprudence in Minnesota and Connecticut and reported "[f]ederal courts apparently

315. See Carl McGowan, Congress, Court, and Control of Delegated Power, 77 Colum. L. REV. 1119, 1128-30 (1977); Richard J. Pierce, Jr., Political Accountability and Delegated Power: A Response to Professor Lowi, 36 AM. U. L. REV. 391, 402-07 (1987); Richard J. Pierce, Jr., The Role of the Judiciary in Implementing an Agency Theory of Government, 64 N.Y.U. L. REV. 1239, 1244-47 (1989).

316. See, e.g., Mashaw, Prodelegation, supra note 47; Richard Stewart, Beyond Delegation Doctrine, 36 AM. U. L. REV. 323 (1987); see also BARBER, supra note 91, at 76 (describing nondelegation doctrine as "heavily encrusted with the constructs of judicial myth-making" and revealing a "judicial propensity to manipulate well-rehearsed formulas for upholding delegations of any kind"); LOUIS JOLFE, JUDICIAL CONTROL OF ADMINISTRATIVE ACTION 51, 56 (1965) (finding courts' reasoning in the nondelegation context as "hopelessly fictional rationalization" and "sheer illusion").

317. See THE COUNCIL OF STATE GOVERNMENTS, supra note 293, at 135-37. 
have much more limited opportunities to participate in institutional interventions that emphasize collegial exchanges rather than separa. tion of powers." 318 Although many state constitutions, like the U.S. Constitution, prohibit courts from exercising jurisdiction until an actual case or controversy is presented, some state constitutions give courts constitutional authority to issue advisory opinions. ${ }^{319}$ As Justice Peters describes, courts in states, including Minnesota and Connecticut, are regularly provided with advance notice of pending legislation and are allowed the opportunity to "influence the language, content, and effect of pending legislation to minimize the risk of future points of conflict." 320 Whether this role of state courts makes it easier for them than their federal counterparts to implement a nondelegation doctrine is questionable, but the institutional difference in roles may make state judges more comfortable in exercising this role.

\section{Institutional Design and the Need for More Continuing Legislative Control, Not Just Oversight}

Institutional differences in the operations of the federal and many state systems of governance also support some degree of divergence in the jurisprudential approaches to legislative control of the agency rulemaking process between federal and state courts. These include some basic principles of state constitutional law, as well as botll legislative and executive features of state governments.

To begin, as a matter of constitutional law, legislative power in the states is fundamentally different than in the federal system. The

318. See Ellen A. Peters, Getting Away from the Federal Paradigm: Separation of Powers in State Courts, 81 MiNN. L. REV. 1543, 1561 (1997).

319. See, e.g., MASS. CONST. pt. 2, ch. 3, art. II (discussing ability of each branch of the legislature and the governor or the council te require the opinion of the supreme judicial court); N.H. CoNST. pt. 2, art. 74 (noting authority by each branch of the legislature and the governor or the council to require the opinion of the justices of the Supreme Court on questions of law and solemn occasions); R.I. CoNST. art. 10, 33 (noting that the justices of the Supreme Court will issue an advisory opinion on any question of law whenever requested by the governor or either house of the legislature); see also CoLO. CONST. art. VI, $\S 3$ (allowing Governor, Senate or House of Representatives te ask Supreme Court for an opinion); FLA. CoNST., art. 4, §10 (allowing the Supreme Court to issue advisory opinions when requested by Attorney General); ME. CONST. art. 6, § 3 (providing Governor, Senate, and House the power to require opinions); MICH. CONST. art. $3, \S 8$ (allowing Governor and either House of legislature to require opinions); S.D. CONST. art. 5, $\S 5$ (providing the Governor the power to require opinions of Supreme Court); ALA. CODE $\S 12-2-10$ (allowing Governor or either house of the Legislature to request an advisory opinion); 29 Del. Laws 2102 (allowing the Governor or a majority of the General Assembly to ask for an opinion).

320. Peters, supra note 318 , at 1561 . In Connecticut, some consultation between courts and the legislature is required by statute. See CONN. GEN. STAT. ANN. § 51-15a (West 1985) (requiring annual consultation between the superior court rules committee and the legislative judiciary committee). 
U.S. Constitution explicitly grants Congress certain powers to pursue broad ends and, under the necessary and proper clause, these powers also carry the subsidiary powers necessary for the achievement of these ends. ${ }^{321}$ Modern state legislatures, much like the enormously powerful Whig legislatures, are not hmited to a listing of enumerated powers, but exercise plenary power. For instance, the Kansas Supreme Court recently stated: "It is fundamental that our state constitution limits rather than confers powers. Where the constitutionality of a statute is involved, the question presented is, therefore, not whether the act is authorized by the constitution, but whether it is prohibited thereby." 322 Thus, many state legislatures have general constitutional authorization for exercising much broader authority than the U.S. Congress. ${ }^{323}$ It should come as no surprise that state legislatures, consistent with their Whig predecessors and Antifederalist principles, see themselves as wielding almost complete sovereignty, absent the exercise of any powers specifically forbidden.

Institutional design features of state governments also provide some explanation of doctrinal divergences and divergences in enforcement levels on issues such as the legislative veto between federal and state systems. The nature of state legislatures suggests a need for more formal oversight of agency governance than exists at the federal level. Since, as is discussed above, ${ }^{324}$ most state legislatures only meet a couple of months a year, the time they are in session is scarce. As bodies of the whole or in their jurisdictional committees, state legislatures are not capable of engaging in regular oversight of agency activities as effectively as the U.S. Congress. When Congress wishes to evaluate a controversial agency proposal, it holds committee

321. Cf. McCulloch v. Maryland, 17 U.S. (4 Wheat.) 316, 421 (1819) ("Let the end be legitimate, let it be within the scope of the constitution, and all means which are appropriate, which are plainly adopted to that end, which are not prohibited, but consist with the letter and spirit of the constitution, are constitutional.").

322. State ex rel. Tomasic v. Unified Gov't of Wyandotte County, 955 P.2d 1136, 1145 (Kan. 1998); see also Pratt v. Allen, 13 Conn. 119, 124-25 (1839) (distinguishing between limited powers conferred to the federal government and the extreme powers of state government); Client Follow-Up Co. v. Hynes, 390 N.E.2d 847, 849 (Ill. 1979) (explaining that since "the basic sovereign power of the State resides in the legislature ... there is no need to grant power to the legislature").

323. "State governments are not restricted in the purposes for which they can exercise power-they can legislate comprehensively to protect the public welfare-and because of this, state constitutional interpretation cannot proceed in terms of a state government's 'important objects' and 'minor ingredients'...." G. ALAN TARR, UNDERSTANDING STATE CONSTITUTIONS 7-8 (1998). A classic statement of this proposition is W. F. Dodd, The Function of a State Constitution, 30 POL. SCI. Q. 201, 205 (1915).

324. See supra notes $291-93$ and accompanying text. 
hearings, as it did in reaction to EPA's proposed clean air regulations in 1997.325 In the course of these hearings, an agency can receive signals-positive and negative-regarding Congress's desires. An agency can also receive early warning of congressional reaction to the agency's decision, such as a possibility of budget cuts or new legislation, and can take this into account when it makes its decisions. Although the legislative oversight process does not always work perfectly, it provides a powerful tool to check the agency rulemaking process at the federal level.

In the states, by contrast, agency-specific oversight hearings are rarely held. When the legislature is in session, it is more likely that the leadership will focus hearings on a handful of high-profile issues, maximizing its public profile during its short life. In addition, staffs of state legislatures, on the whole, are not as experienced and sophisticated as staff members in the U.S. Congress. Even if the legislature is able to hold agency-specific oversight hearings, the level of understanding of agency decisionmaking is likely to be much lower than at the federal level. A final factor likely to influence state doctrine and enforcement levels in the context of legislative review of rules is the reality of reduced executive power and supervision abihty, which are not likely to be as effective as the U.S. President's. ${ }^{326}$

Because of these problems with regnlar formal and informal oversight, many states institutionalize rules review in the legislature by estabhshing a special "rules review" committee. ${ }^{327}$ In many states, institutionahized legislative review is of much greater utility than at the federal level. Of course, to the extent the state legislative process is dominated by factionalized decisionmaking, this is not always a positive feature of state agency decisionmaking. But, for part time legislatures, it has become essential to the functioning of state governments. For these institutional reasons, state legislatures hold on dearly to rules review mechanisms, such as the legislative veto. As a practical matter, a state legislature's rules review mechanism, even if unconstitutional, is unlikely to be challenged successfully because any

325. The EPA's 1997 clean air rules established stringent new standards for ozone and for particulates. See John H. Cushman, Jr., Clinton Sharply Tightens Air Pollution Regulations Despite Concern Over Costs, N.Y. TIMES, June 26, 1997, at A1. The EPA and Clinton Administration proposed fairly stringent standards, but congressional hearings and input tempered the standards adopted by the agency. See Alexandra Marks, Losers in Smog Battle Try End-Run Attack, CHRISTIAN SCI. MONITOR, Aug. 14, 1997, at 3. The EPA's regulations were reversed and remanded by the D.C. Circuit in American Trucking Association, Inc. v. EPA, 175 F.3d 1027 (D.C. Cir. 1999). See supra notes 60-61 and accompanying text.

326. For discussion, see supra notes 300-310 and accompanying text.

327. See supra Part III.C. 
agency doing so is almost certain to be subject to retaliation. ${ }^{328} \mathrm{So}$, at the state level, some underenforcement of restrictions such as those at issue in Chadha may be expected. Thus, due to institutional design, states continue to hold on to strong legislative control, such as committee veto, committee-triggered delays of rulemaking, and committee-triggered burden shifting, even where these are constitutionally suspect.

\section{Constitutional Interpretation and Institutional Design}

An explicit acknowledgement of aspirational principles for separation of powers and an awareness of institutional design are necessary to justify the Antifederalist legacy that continues in many states. Institutional design features informing separation of powers doctrine are something more than values that differ from state to state, or between the state and national systems of governance, as many of advocates of the new judicial federalism assert. ${ }^{329}$ Although differences in details abound, institutional design features of many state systems of governance, such as the structure of the executive branch, may have influenced separation of powers doctrines, including state adherence to Antifederalist principles. Judicial recognition of institutional features would help to identify the aspirational pohty represented in a state's constitution and the practical necessities of governance that sustain or thwart it. ${ }^{330}$

In addition, institutional design features should inform how state courts use precedents from the U.S. Supreme Court or from the high courts of other states. The examination of institutional features that influence state separation of powers jurisprudence suggests some lessons for state courts attempting usage of extra-jurisdictional authority in the separation of powers contexts. Given variations in text and institutional structure, rarely will an authority from another jurisdiction squarely resolve the interpretive question of state constitutional law. To the extent institutional design factors contribute to the path of state separation of powers jurisprudence, an acknowledgement of these factors can improve the reasoning of state court opinions addressing separation of powers issues. Attention to such

328. Examples of state roles review processes that are suspect under Chadha are summarized supra notes 246-68 and accompanying text.

329. On this position, see sources cited supra note 3.

330. See Schapiro, supra note 285 , at $455-56$ (suggesting that state constitutions represent aspirational, rather than preexisting, values). 
factors will make judicial opinions more accessible to and usable by courts in other states, and will bring attention to the relationship between institutional design and legal doctrine.

Yet the infrequency with which state courts acknowledge institutional differences in using authority from other jurisdictions is astounding. In many state cases, separation of powers analysis becomes a counting game-a "mee-tooism" ${ }^{331}$-where a court simply cites the number of state opinions accepting a certain type of statute and the number rejecting it, usually as support for siding with the majority of states having previously considered the issue. In Colorado, for example, the Supreme Court, in upholding the constitutionality of the state's Agricultural Marketing Act, stated:

We have read opinions from twenty-one states which have upheld marketing acts comparable to the one adopted in Colorado. In six states we have found decisions which have held such acts, in certain particulars, to be unconstitutional. The great weight of authority seems to uphold marketing acts which are framed in language similar to that found in the Colorado law. ${ }^{332}$

The court made no effort to refer to the texts of these state's constitutions, nor did it make any effort to address similarities and differences with Colorado's governmental structure.

One of the more notable recent nondelegation cases, Texas Boll Weevil Eradication Foundation Inc. v. Lewellen, also failed to adequately acknowledge how institutional design features and their tendency to influence faction in state agency decisionmaking support adherence to a strong nondelegation doctrine. The court noted that state courts "have historically been more comfortable" striking laws on nondelegation grounds than their federal counterparts, but failed to provide any normative or institutional reason for this difference in constitutional doctrine. ${ }^{333}$

The approach of the court in striking down private delegations illustrates how attention to the relationship between institutional design and incentives affecting private behavior can inform state nondelegation doctrine. Often, in states such as Texas, even where delegation is made to a collegial public board, the structure of the board is such that it is effectively similar to a private governance

331. John Frank, a prominent appellate lawyer, describes the general state of state constitutional law as inclined towards "a sort of pallid me-tooism." John P. Frank, Symposium: The Emergence of State Constitutional Law, 63 TEX. L. REV. 1339, 1340 (1985) (book review).

332. Swisher v. Brown, 402 P.2d 621, 628 (Colo. 1965) (en banc).

333. Texas Boll Weevil Eradication Found., Inc. v. Lewellen, 952 S.W.2d 454, 468 (Tex. 1997). The case is discussed in more detail supra notes $122-29$ and accompanying text. 
board, such as the agency at issue in Boll Weevil. For example, many state licensing boards, such as those that set standards for doctors, engineers, or barbers, are comprised of several members of the profession regulated and an at-large member, intended to represent consumer interests. These agencies, like a state legislature, may meet infrequently, have limited staff, and are comprised of amateurs rather than civil servants. The decisionmaking process of this type of board is more likely to be captured than delegation to a more directly accountable executive branch agency. State judicial adherence to a strong nondelegation doctrine can therefore be explained as a judicial effort to limit faction and its contribution to capture in agency decisionmaking. ${ }^{334}$ Reference to institutional features of state constitutions, such as the fragmented executive, ${ }^{335}$ might provide some rationale to support adherence to a strong nondelegation doctrine in states such as Texas, as these features will influence the degree of faction and likelihood of capture.

This is not to suggest that state courts should-or will-always strike down delegation to a private or collegial board for regulatory purposes. Contrast Boll Weevil to Florida's approach in assessing delegation to a private board. In State Department of Citrus $v$. Griffin, the Florida Supreme Court upheld a legislative delegation to the Citrus Commission, composed of members of the orange industry, to issue marketing orders. ${ }^{336}$ The marketing orders were intended to assist the industry in stabilizing supply and demand in response to market shocks brought on by natural catastrophes or overabundant supply. ${ }^{337}$ Although Florida, like Texas, is a strong nondelegation state, the Florida Supreme Court upheld the delegation, observing "judicial scrutiny ought to be accompanied by recognition and appre-

334. The Texas Supreme Court explained: "[W]e believe it axiomatic that courts should subject private delegations to a more searching scrutiny than their public counterparts." Id. at 469. Other states courts have also struck down private delegations. See e.g., Hillman v. Northern Wasco County People's Util. Dist., 323 P.2d 664, 674 (Or. 1958) (invahdating a statute that adopted an electrical code of a private organization of electricians, who had authority to amend the code in the future, and made violations of the code unlawful). Many states have invalidated statutes that delegate to private accrediting agencies the power to determine members of a profession, such as medicine or pharmacy. See, e.g., Garces v. Department of Registration and Educ., 254 N.E.2d 622 (Mll. App. Ct. 1969); Gumbhir v. Kansas State Bd. of Pharmacy, 618 P.2d 837 (Kan. 1980).

335. See supra note 304 (referring to Texas' long ballot); see also Bruff, supra note 16, at 1346.48 (noting influence of reduced executive power on nondelegation).

336. State Dep't of Citrus v. Griffin, 239 So. 2d 577, 580-81 (Fla. 1970).

337. See id. at 578. 
ciation of the need for flexibility."338 Protecting against market shocks is the type of regulatory action for which sliort-term flexibility is more valuable than defining geographic pest eradication zones, as in Texas' recent Boll Weevil case. ${ }^{339}$ Thus, although the goals of accountability and protection against faction may influence some states to endorse a strong nondelegation doctrine, especially in the private delegation context, state courts also appear to balance the need for flexibility in achieving a regulatory program's purposes against these goals.

State courts' concerns witl faction and capture relate closely to issues of institutional design. This relationship becomes more apparent when examined in the context of a continuing puzzle of state nondelegation jurisprudence, delegation to a federal agency. In many states that endorse a strong nondelegation doctrine, the legislature has delegated some aspects of regulation to federal agencies, often witlout any definition of standards or safeguards by the state legislature. For example, a challenged provision of the Texas Solid Waste Disposal Act criminalized the transportation, storage, processing, disposal, and export of "hazardous waste," defined as "solid waste identified or histed as a hazardous waste by the administrator of the United State Environmental Protection Agency...."340 A Texas appellate court noted that this delegation "may be read to say the legislature lias delegated to the EPA the power to define hazardous waste. . and that the definition may cliange from time to time at the will of the EPA ...." but also observed that such a construction would "place in doubt" the constitutionality of the statute. ${ }^{341}$ Thus, somewliat disingenuously, the court read tlie statute to incorporate by reference the EPA's definition of solid waste at the time of enactment of the Texas statute, but not modifications adopted by the EPA afterwards. $^{342}$

338. Id. at 581 .

339. Boll Weevil involved a delegation of power to set geographic zones and to finance and enforce pest eradication, without providing specific guidance for the definition of these zones. These zones, unlike market supply and demand conditions, would be unlikely to change significantly from year to year, and thus there would seem to be less of a need for flexibility in implementing Texas' pest eradication program than Florida's orange industry stabilization program. A later Florida case, Askew v. Cross Key Waterways, 372 So.2d 913 (Fla. 1979) (discussed supra notes 135-39 and accompanying text), invalidated a delegation of authority to define geographic areas of critical state concern for purposes of managing development, a regulatory context in which flexibility is not as important as in Griffin.

340. TEX. HEALTH \& SAFETY CODE ANN. $§ \S 361.221(a)(1)$-(2) (stating transport of hazardous waste to unauthorized locations is a criminal offense) (later repealed by acts 1997, $75^{\text {th }}$ leg.ch. 107; $\S 361.003(15)$ (West 1992).

341. Ex parte Elliott, 973 S.W.2d 737, 741 (Tex. App. 1998).

342. See id. at 742-43. For a case that held the state legislature's delegation to a federal agency unconstitutional, see City of Oklahoma City v. Oklahoma Dep't of Labor, 918 P.2d 26, 28 
The Texas court did not need to read the statute this way to uphold the delegation. In many states, the delegation doctrine is applied differently where the delegation is made to a federal, rather than state, decisionmaker. Courts have upheld state legislature delegations of authority to a federal agency, including future lawmaking authority, even where the state nondelegation doctrine has not been met. For example, in McFaddin $v$. Jackson, the Tennessee Supreme Court upheld a statute that made individual retirement plans taxable if subject to the federal estate tax, but exempt if excluded from the federal estate tax. ${ }^{343}$ Articulating concerns of uniformity and administrative simplicity in conforming tax statutes, the court reasoned that the delegation was constitutional despite the legislature's failure to provide adequate standards and safeguards. ${ }^{344}$ Also, in Florida, the Supreme Court upheld a statute that made unlawful "unfair . . . acts or practices in the conduct of any trade or commerce" and instructed state regulators to adopt regulations consistent with the Federal Trade Commission's. ${ }^{345}$

The conventional explanation for this difference in delegation outcome depending on the decisionmaker is that a state legislature's delegation to a federal agency may, in certain contexts, promote uniformity. ${ }^{346}$ However, attention to institutional design provides an alternative explanation for this nondelegation puzzle. Regardless of a regulatory scheme's purposes, the institutional design features of federal agencies may also make the possibility of capture and factional interference in the agency lawmaking process less likely. In the states, reduced legislative oversight, due to limited sessions, and reduced executive oversight, due to plural offices in the executive branch, may make capture of an agency's decision making process more likely than at the federal level. In addition, many federal agencies will be superior at making technical decisions that require regular revision than their state counterparts. Judicial decisions addressing delegation to federal agencies have failed to address institutional

(Okla. 1995) (striking as unconstitutional a statute that stated that the prevailing hourly wage rate for Oklahoma would be determined by the United States Department of Labor).

343. McFaddin v. Jackson, 738 S.W.2d 176, 176-77 (Tenn. 1987).

344. See id. at 182.

345. Department of Legal Affairs v. Rogers, 329 So. 2d 257, 262-63 (Fla. 1976).

346. One commentator argues that courts addressing the constitutionality of such delegations should address the importance of uniformity in the area regulated. See Arnold Rochvarg, State Adoption of Federal Law-Legislative Abdication or Reasoned Policymaking, 36 ADMIN. L. REV. 277, 298 (1984). 
design factors that might make the delegation more acceptable depending on who the agency decisionmaker is.

State court examination of separation of powers as a constraint on legislative oversight is no better in its acknowledgement of institutional design factors. In recent cases addressing this issue, state courts use federal authority coupled with reference to the number of states concurring with little or no explanation of institutional similarities beyond simple reference to presentment, bicameralism, and veto requirements in the state constitution's text. ${ }^{347}$ An acknowledgement of institutional design factors might focus on the ideals of legislative supremacy that drive states' continued adherence to formal committee review, underenforcement of Chadha norms, and suspect mechanisms such as temporary committee suspension.

More insightfully, an appreciation of institutional design will help to explain the continuing survival in many states of formal legislative oversight mechanisms that appear to violate Chadha. The constitutionality of legislative review provisions in many states may not have been fully litigated because of strong incentives against challenge at the state level. State agencies may be reluctant to challenge legislative review mechanisms, in large part because they fear retaliation by the legislature. Where these review mechanisms have been challenged, state agencies, fearing legislative retaliation, may face strong incentives to settle or compromise.

This also seems to be the case at the federal level where hundreds of legislative vetoes have been adopted into law since Chadha, ${ }^{348}$ but enforcement of Chadha separation of powers principle is even weaker in many states. First, unlike post-Chadha legislative review mechanisms at the federal level, which are often not explicit and visible, in many states' legislative vetoes, waiting periods, and shifting burdens are explicitly endorsed in statutes. Second, in many states these review mechanisms are general in nature, applying to all agency rules, and are not himited to subject-specific legislation as they are at the federal level. Because of these factors, the bargaining power of any individual agency wishing to contest legislative control politically is much weaker than at the federal level. At the same time, the fear of retaliation by the legislature might discourage legal challenge of the legislative review process, as in North Carohna. ${ }^{349}$ Thus, more general and sweeping legislative review mechanisms,

347. See supra notes 194-227 and accompanying text (discussing Missouri and Michigan cases).

348. See supra notes $80-86$ and accompanying text.

349. For examples, see supra notes 257-68 and accompanying text. 
which are suspect under Chadha, survive in many states than at the. federal level. So, for institutional design reasons, separation of powers restrictions on legislative oversight may be "underenforced" constitutional norms in many states. ${ }^{350}$

This strand of separation of powers teaches a lesson to separation of powers students: in assessing constitutional divergences between the federal and state systems on issues such as constitutional limitations on legislative oversight, courts and scholars should not only pay attention to doctrine but also to differences in enforcement levels, an issue that requires a fuller appreciation of the micro-politics of state bureaucratic decisionmaking.

In each of these contexts-nondelegation and the legislative oversight-acknowledgement of a theory of separation of powers and discussion of institutional design features that might have influenced this theory could work to strengthen our understanding of courts, agencies, and the legislature in developing and enforcing separation of powers principles. Discussion of these features is a necessary predicate to understanding the Antifederalist legacy, constructing an independent state theory of separation of powers, and identifying institutional reforms that may be necessary to bring about changes in the approaches of state courts.

\section{CONCLUSION}

Many state courts, in interpreting state constitutions, use separation of powers to limit delegation and expand the power of the legislature to control agency rulemaking in a manner consistent with Antifederalist political science. The approach of such states differs starkly from that of federal courts, which have interpreted separation of powers to favor delegation to administrative agencies and to himit legislative oversight in a manner consistent with Federalist separation of powers principles. Yet state courts rarely provide discussion of or reference to these differing principles, nor do they provide adequate rationales for adherence to a distinct state approach.

The state approach can be critiqued through the normative lens of Federalist separation of powers principles. While this may appease those who agree with the prodelegation position and its Fed-

350. Cf. Lawrence Gene Sager, Fair Measure: The Legal Status of Underenforced Constitutional Norms, 91 HARV. L. REV. 1212 (1978). 
eralist framework, the superimposition of federal separation of powers jurisprudence onto the states ignores the value of independent state interpretations of state constitutions, a key tenet of the new judicial federalism..$^{351}$ The results alone of federal courts are of limited help to state courts as they address the particular problems their own systems of governance face, although state courts might find analogies in the reasoning approach of many federal decisions addressing similar separation of powers issues.

At the same time, other theories of constitutional interpretation, such as textual and character-based arguments, are also of little value in reconciling the cases or in making sense of the approaches of state courts. As I have argued, attention to institutional designexamining the particular governance institutions of a given state and how these institutions effect the operation of agency governance-can provide some explanation for many state court approaches to separation of powers issues affecting administrative agencies, particularly where these approaches diverge from federal case law. It has not been my intent to justify or explain state decisions that have little support in a serious analysis of institutions and their operation. Many state courts reject or follow the federal approach to separation of powers issues with hittle more than textual and doctrinal analysis. In interpreting their constitutions, state courts should make efforts to recognize and explain key institutional features of state governance that differ from the federal system, and to take seriously institutional differences between the states. This can help states in identifying the basis for adherence to distinct separation of powers principles and in gauging the ability of their system of governance to achieve Antifederalist principles.

State constitutional law has been described by James Gardner as a "vast wasteland of confusing, conflicting, and essentially unintelligible pronouncements." ${ }^{352}$ Writing over 40 years ago, Kenneth Culp Davis, then an authority in the laws governing the growing administrative state, wrote of state courts considering the nondelegation issue, "the typical opinion strings together some misleading legal

351. For more discussion on the values of independent state interpretation of constitutions, see James D. Heiple \& Kraig James Powell, Presumed Innocent: The Legitimacy of Independent State Constitutional Interpretation, 61 ALB. L. REv. 1507 (1998). See also Rodriguez, supra note 9; Robert F. Utter, State Constitutional Law, The United States Supreme Court, and Democratic Accountability: Is There a Crocodile in the Bathtub?, 64 WASH. L. REV. 19, 46-47 (1989); Robert F. Williams, In the Supreme Court's Shadow: Legitimacy of State Rejection of Supreme Court Reasoning and Result, 35 S.C. L. REV. 353 (1984).

352. James A. Gardner, The Failed Discourse of State Constitutionalism, 90 MICH. L. REv. 761,763 (1992). 
1240

VANDERBILT LAW REVIEW

[Vol. 52:1167

cliches and announces the conclusion."353 While I believe that Gardner and Davis may be correct in their description of state judicial reasoning in the separation of powers context, unlike Gardner I do not believe that the development of a unique state constitutional approacl in the separation of powers context would be mistaken. Perhap state courts have made a mistake in continuing the legacy of Antifederalist separation of powers ideals, to the extent they do so. However, in this Article I suggest that institutional design may have sustained the Antifederalist legacy in some states. Discussion of institutional features affecting doctrine may assist state courts in salvaging their interpretive approach to separation of powers in the administrative rulemaking context. At the same time, though, I do not believe that differences in state systems of governance always outweigh their similarities with the federal system. If state courts are not able to legitimately salvage their interpretive approach, the Antifederalist bias of their separation of powers jurisprudence-and its concomitant anti-delegation approach to agency rulemaking-should be reassessed.

353. 1 DAVIS, supra note $44, \S 2.07$ at 102 . 